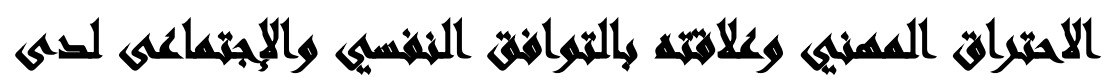

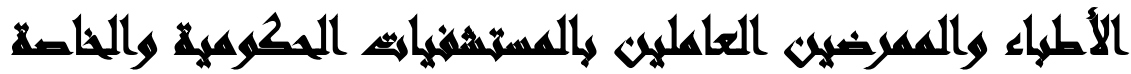

[IT]

\author{
جمال شفيق أحمد(')- أحمد عصمت السيد(r)-- منى محمد كمال الدين(r)

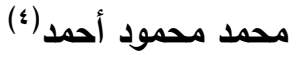

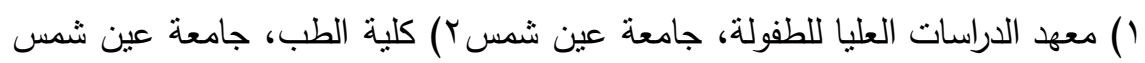

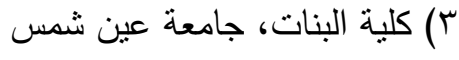

\section{المستخله}

يهدف البحث الراهن إلى الكثف عن العلاقة بين الاحتراق المهني وعلاقته بالتوافق

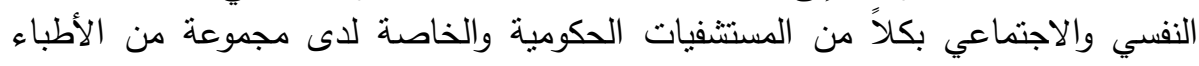

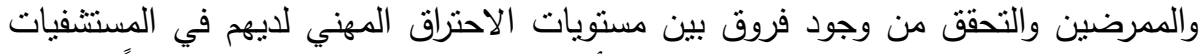

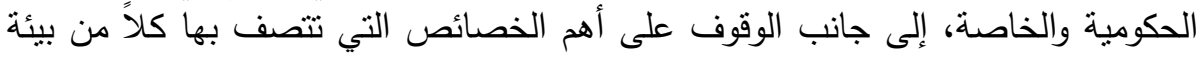

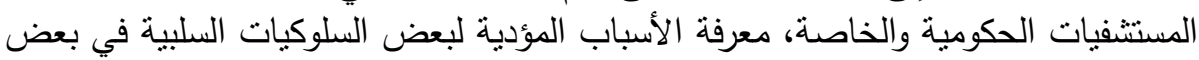

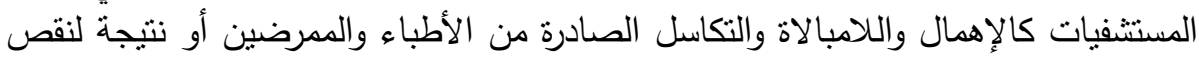

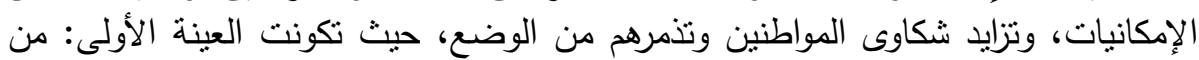

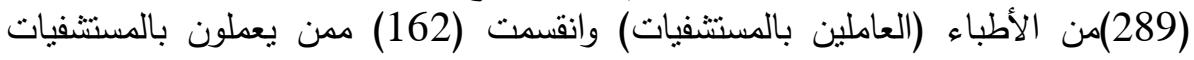

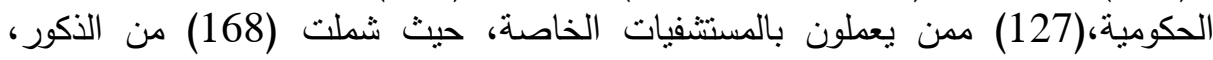

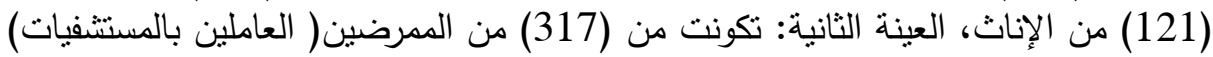

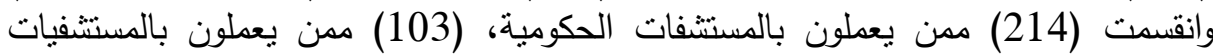

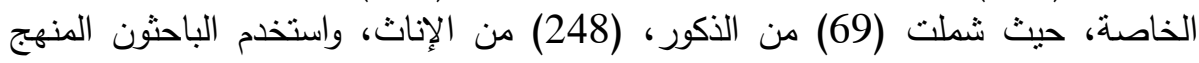

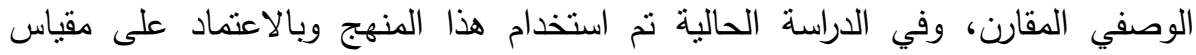

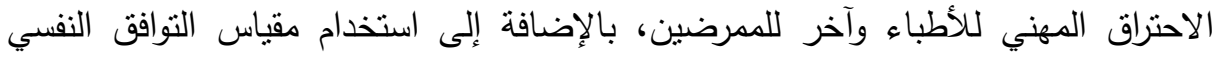

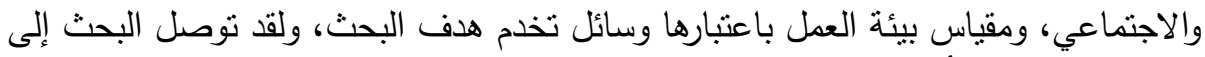

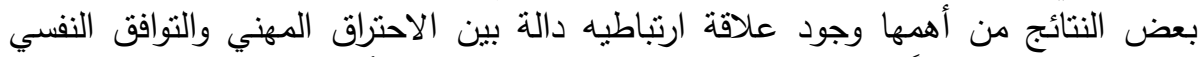

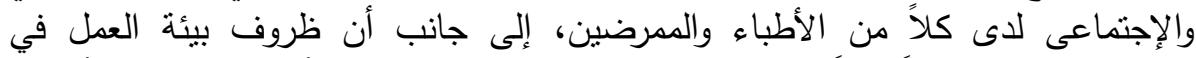

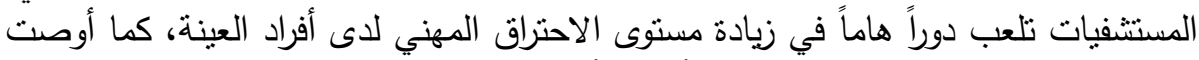

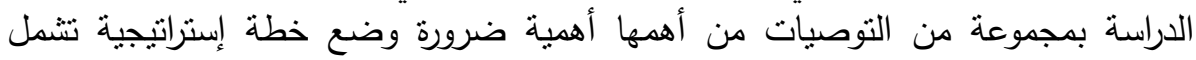

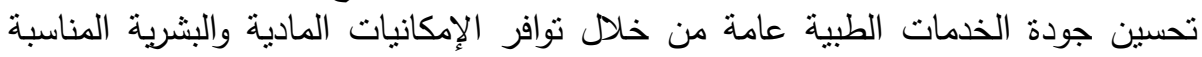

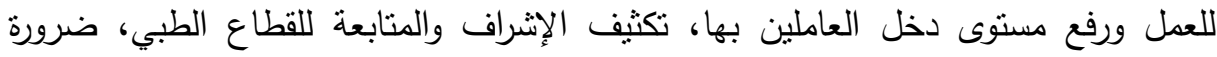

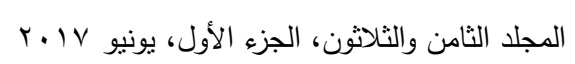




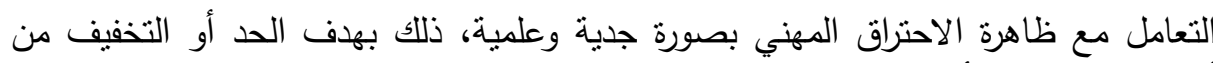
أثارها السلبية على أداء الأطباء والممرضين، وغيره.

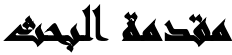

وصف باحثّن العصر الحالي بأنه عصر الضغوط النفسية Psychological) لذلك أصبحت من الظواهر التي تتطلب من الإنسان (burn out)(stress) التعايش معها وتطوير كفاء ته للتعامل معها، فالاحتراق المهني مرض عصري شاع في الفترة

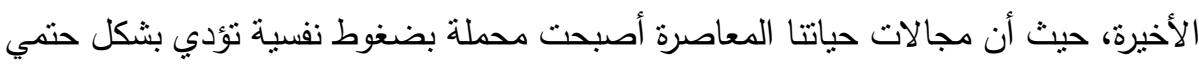
إذا استمرت لفترات طويلة وبشكل متكرر للاحتراق المهني، وقد اكتسب موضوع الاحتراق المهني أهمية كبيرة لدى الباحثثن في العديد من الدول المتقدمة خلال الفترة الماضية في عدة

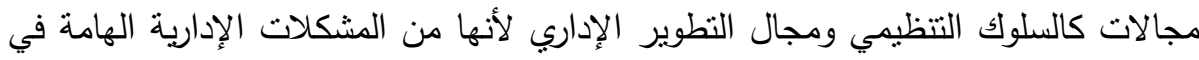
عالمنا المعاصر التي تواجه العاملين في المنظمات الحكومية وغير الحكومية، ويعتبر مؤشرا

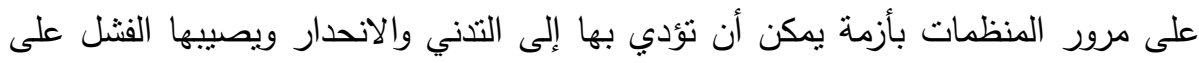
المدى الطويل للآثار السلبية على المنظمات والعاملين بها.(محمد الزيودى، 2007،

$$
\text { ضيف الله النفيعى، }
$$

ويحدث الاحتراق المهني عندما لا يكون هناك توافق بين طبيعة العمل وطبيعة الإنسان الذي ينخرط في أداء ذلك العمل، وكلما زاد التباين بين هاتين البيئتين زاد الاحتراق الذي يواجه الفرد في مكان عمله إلى جانب تداخل ظاهرة الاحتراق المهني للشخص مع ظواهر أخرى متتشابكة ومنها اتجاهات الفرد نحو المهنة، والرضا الوظيفي، وكفايات الموظف، والتفاعل الاجتماعي، والسلطة الإدارية. وربما يعد اتجاه الفرد نحو المهنة هو المحدد الأساسي لمدى ولى لهي

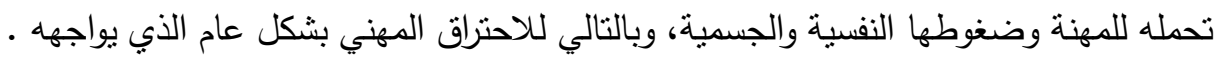
وأثنارت ماسلاش إلى أن أساس الاحتراق المهني يكمن في عدة عوامل تتركز في الظروف بله

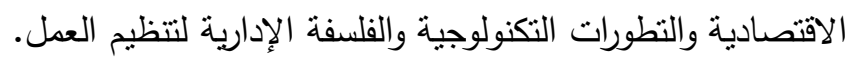


هذا وقد نطور الاهتمام بظاهرة الاحتراق المهني بين الباحثين والممارسين، على حد

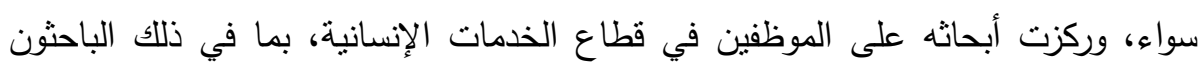

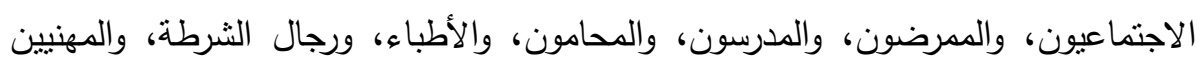

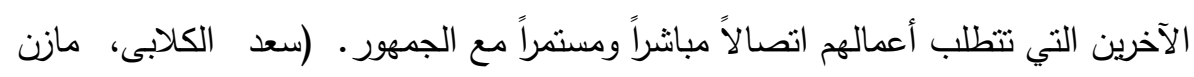

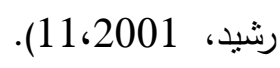

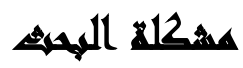

إن التطور السريع في كافة الميادين الاجتماعية،السياسية،الاقتصادية،الثقافية.....الخ،

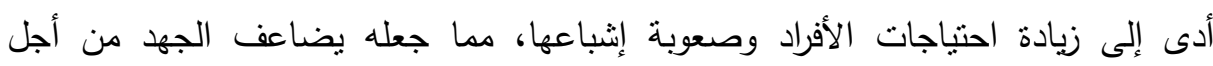

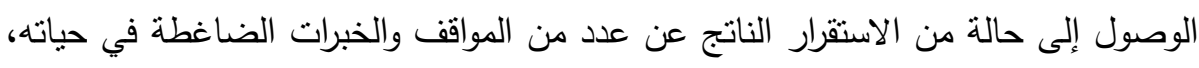

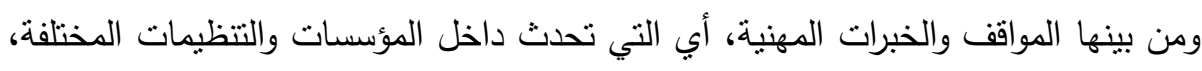

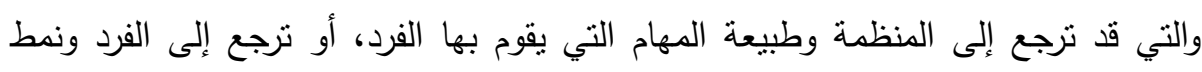
شخصيته، إلا أن مستويات الضغط المهني داخل المؤسسات تختلف كماً وكيفاً عن بعضها البعض، ويعتبر قطاع الصحة من أكثر القطاعات عرضة للضغوط، حيث يعد من القطاعات

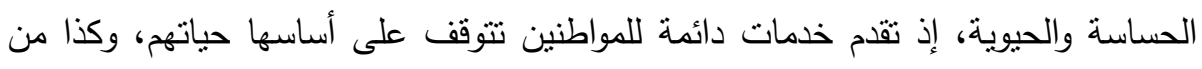
المؤسسات التي تقوم على العمل المنسق والأداء الفعال بين جميع القائمين والعاملين في تلئي القطاع وخاصة الأطباء منهم، وذللك راجع لطبيعة مهنتهم التي نتطلب الدقة في تشخيص المرض وتحديد العلاج المناسب، وأخذ الحيطة والحذر من الأمراض المعدية والانتباه الدائم

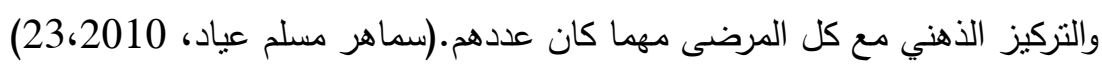
وعلى الصعيد الآخر بالنسبة لمهنة التمريض فالممرضون العاملون والممرضات العاملات في المستتفيات يتعرضون إلى درجات متباينة من الضغوط النفسية والاجتماعية

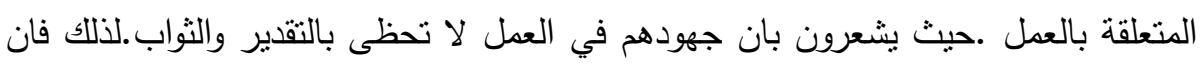

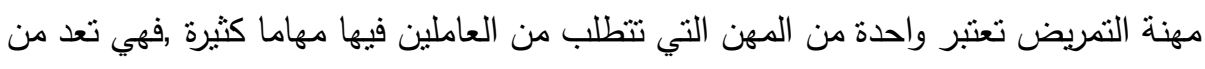

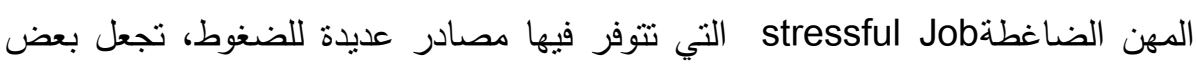
الممرضين و الممرضات غير راضين وغير مطمئنين عن مهنتهم,مما تترتب عليه آثار سلبية تتعكس على كفاءة ذاتهم وتوافقهم النفسي والمهني، ويعد التمريض ركنا أساسيا في

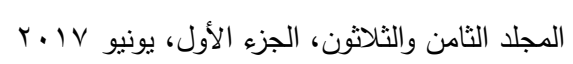


المستشفيات، وإن نجاح أو فثل هذه المستشفيات يعتمد عليه بشكل أساسي، ولهذا فلابد من تقدير هذا الدور الذي يلعبه طاقم التمريض في تطويرها. (جودة يحيى عبد الجواد، 2003،

وقد أثنارت عديد من الإحصائيات ضغط العمل الثديد يتسبب فيما العديد من المشكلات النفسية من أهمها الأعراض النفسجمية، وهى الأمراض التي سببها نفسي ومن العوامل النفسية التي تثيرها البطالة والظروف الاقتصادية السيئة وتعتبر المهن الخدمية هى أكثر المهن

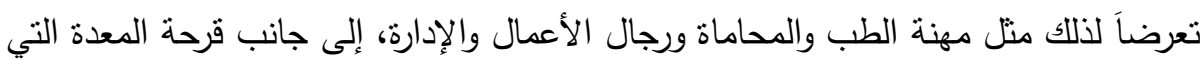

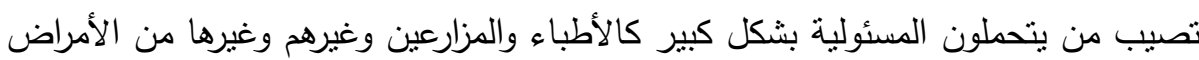
النفسية التي نؤثر بشكل كبير على العاملين بها. وتتوالى المشكلات السلوكية التي يعانى منها هؤلاء الأفراد، وتبدأ نظهر علئر علامات الاحتراق أو الضغط الثديد الذي يعانون منه الأفراد في سلوكياتهم من خلال تغيرات في أنماط السلوك مثل اضطرابات النوم والأكل، التخخين واللامبالاة، التفكير المضطرب، تهني، تهويل

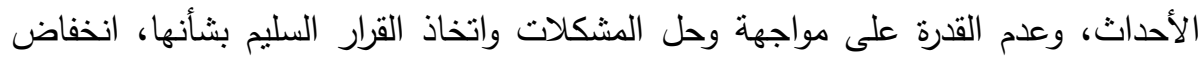

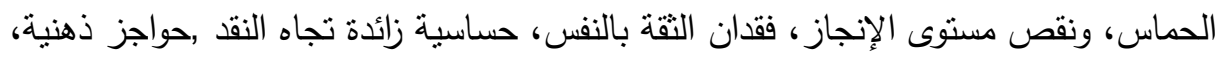
وينعكس الاحتراق المهني على أداء الفرد العامل في مهنته مما يتسبب في خسائر للمنظمة

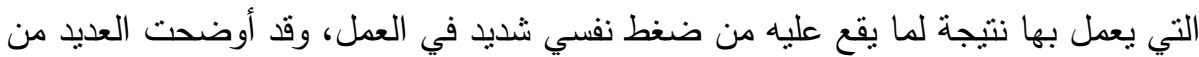
الدراسات أن الضغوط الثديدة في العمل تعتبر العامل الرئيسي في حدوث العديد من فن فئن المشكلات التتظيمية مثل: الأداء المنخفض، دوران العمل، التغيب، التسرب الوظيفي، حيث

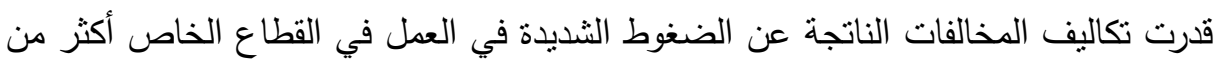
(150بليون دولار) مما أدى إلى انخفاض الإنتاجية والعجز عن العمل، وأن معدل ما تدفعه المنظمات للفرد العامل كتعويض عن ضغوط العمل حوالي (خمسة عشر ألف دولار) وهذا يساوى ضعف المطالبات الناجمة عن الإصابات الجسمية بسبب العمل). (عبد الرحمن

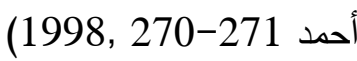


ومما لاثك فيه أن ارتفاع معدل الإحساس بالاحتراق المهني سواء للأطباء أو للممرضين

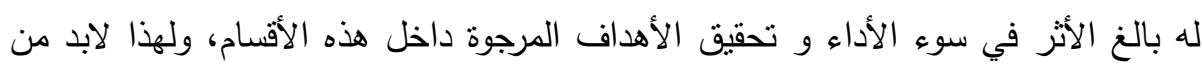

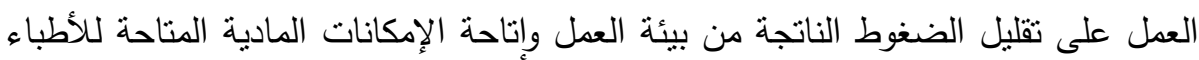

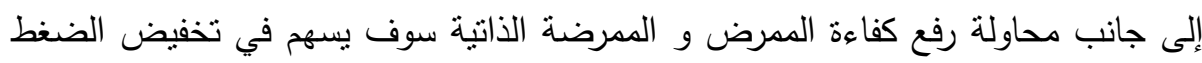
النفسي الناتج من هذه البيئة.

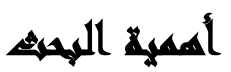

ينطوي هذا البحث على أهية من الناحية النظرية والعملية التطبيقية: ا ) من الناحية النظرية:

- أهمية عملية التوافق النفسي والإجتماعى التي تعبر عن مدى قدرة الفرد على تحقيق أهدافه

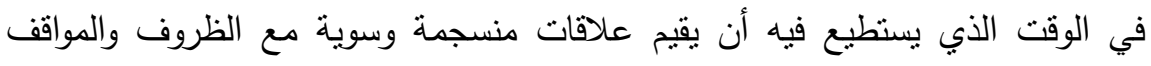
والأشخاص الموجودين في البيئة المحيطة.

- أهمية دراسة العلاقة التطبيقية بين الاحتراق المهني وكلاً من التوافق النفسي والاجتماعي للأطباء والمررضين في المستشفيات الحكومية والخاصة.

- المساهمة في استحداث استراتيجيات جديدة للتعامل مع الأطباء والممرضين ومعرفة العوامل وله

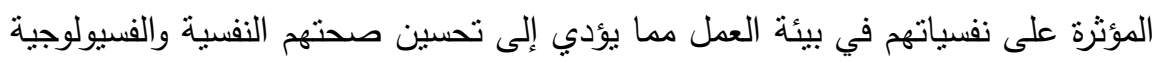
والسلوكية والذي ينعكس على ارتفاع أدائهم ويسهم في تحسين ورفع إنتاجية العاملين في

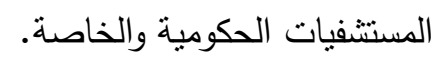

\section{ب) من الناحية التطبيقية:}

- عرض لمشكلة الاحتراق المهني باعتبارها من الموضوعات الهامة لما لها من آثار سلبية

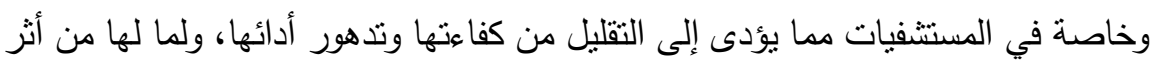
كبير على العاملين بها من أطباء وممرضين فيما يتعلق بصحتهم النفسية والبدنية

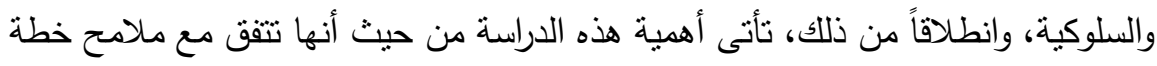

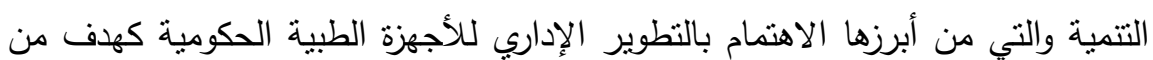


- معرفة الأسباب المؤدية لبعض السلوكيات السلبية في بعض المستشفيات كالإهمال

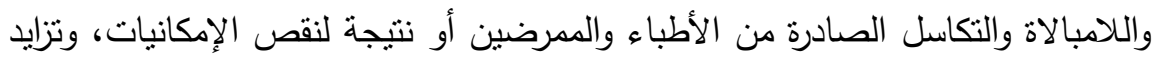
شكاوى المواطنين وتذمرهم من الوضع.

- أهمية بيئة المستشفى باعنبارها ملجأ للتمريض والعلاج ومزاولة الصحة الوقائية وبث النقافة الصحية بين الجمهور ومعالجة الثئون الخاصة بالمريض وتوفير الإمكانيات المادية الجيدة والمناسبة لاسنتفاء المرضى. لئ.

\section{أهساهن المهيش}

يسعى البحث إلى تحقيق مجموعة من الأهداف يمكن تقسيمها إلى:

• تحديد مستوى الاحتراق المهني الذي يعانى منه الأطباء والممرضين في المسنتفيات الحكومية والخاصة. • التعرف على طبيعة العلاقة بين الاحتراق المهني وكلاً من التوافق النفسي والإجتماعى ولفي

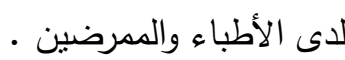
• الوقوف على الخصائص التي تتصف بها بيئة المستشفيات الحكومية والخاصة (بيئة العمل) وتأثيرها على تقديم الخدمة العلاجية المقدمة للمرضى. • الكثف عن الفروق بين مستويات الاحتراق المهني لاى الأطباء والممرضين العاملين بالمستشفيات الحكومية والخاصة. • عرض لمشكلة الاحتراق المهني وتأثثرها على تحقيق التوافق النفسي والإجتماعى للأطباء باء والممرضين وذلك من خلال تحديد مفهوم الاحتراق المهني وأبعاده بشكل نظري.

\section{هزوض المهنه}

تتبلور فروض الاراسة في الفروض الآتية: • توجد علاقة ارتباطيه ذات دلالة إحصائية بين متوسط درجات الاحتراق المهني والتوافق

$$
\text { النفسي والاجتماعي لدى الأطباء. }
$$


• توجد علاقة ارتباطيه ذات دلالة إحصائية بين متوسط درجات الاحتراق المهني والتوافق

$$
\text { النفسي والاجتماعي لاى الممرضين. }
$$

توجد علاقة ارتباطيه ذات دلالة إحصائية بين بيئة العمل ومنوسط درجات الاحتراق لاى لإى

كلاً من الأطباء والممرضين.

\section{التراسايت الماريهي}

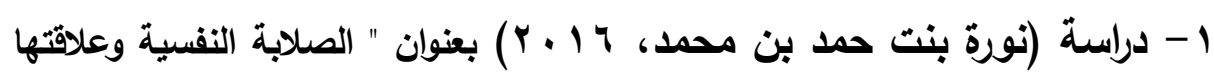
بالاحتراق النفسي لاى عينة من الأخصائيين النفسيين في سلطنة عمان ".هدفت إلى

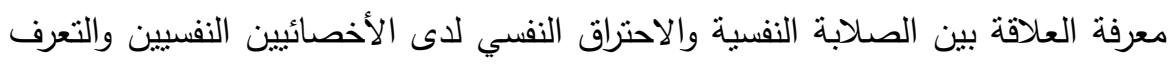
على توضيح الضغوط النفسية والوظيفية التي تؤدى إلى الاحتراق النفسي وتكونت العينة

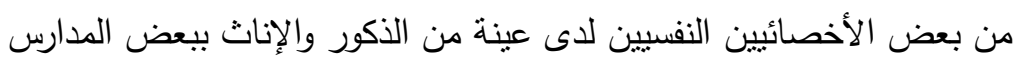
واستخدمت الباحثة مقياس للاحتراق النفسي-مقياس الصلابة النفسية، بالاعتماد على على لإنى المنهج الوصفي الارتباطي وأسفرت النتائج على وجود علاقة بين الصلابة النفسية والاحتراق

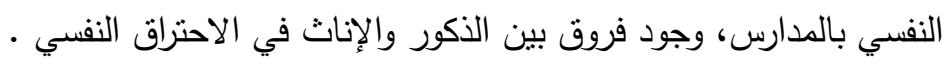

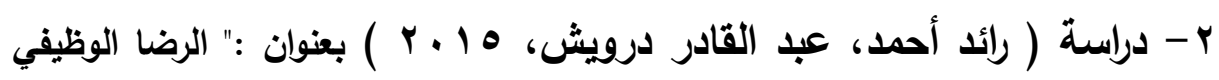
وأثره على جودة الخدمة الصحية في المستثفيات الدكومية العاملة في جنوب الضفة الغربية ". هدفت الدراسة إلى التعرف على الرضا الوظيفي وأثزه على جودة الخدمة

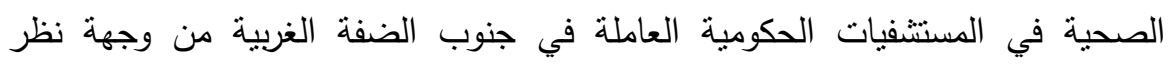

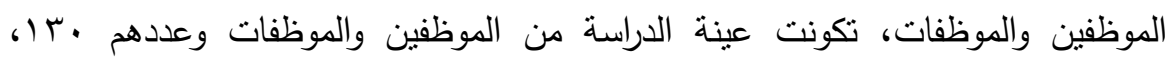
واستخدمت الدراسة المنهج الوصفي الارتباطي، اعتمدت الدراسة على الاستبانة كوسيلة

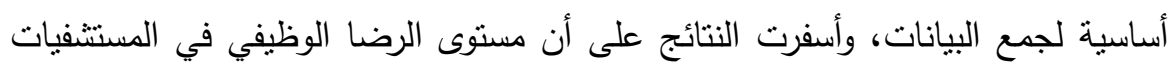
الحكومية العاملة في جنوب الضفة الغربية كان بشكل عام عالي على جميع محاور الدراسة، أن هناك علاقة طردية بين الرضا الوظيفي وجودة الخدمة الصحية حيث أن كلما

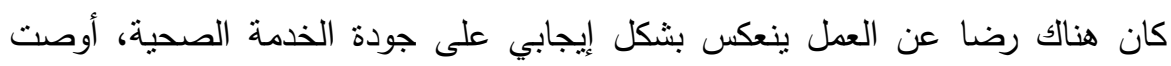


الدراسة بضرورة أن نولى إدارات المستشفيات أهمية خاصة للرضا الوظيفي لدى العاملين وذللك بالعمل على توفير ظروف العمل المناسبة التي تحوز على رضا الموظفين.

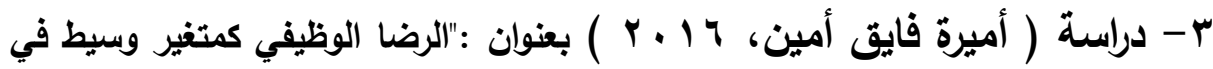
العلاقة بين الاحترق النفسي والعلاقات الأسرية لاى الموظفين بالمحاكم من الجنسين ".هدفت الدراسة إلى الكثف عن الدور الوسيط للرضا الوظيفي في العلاقة بين الاحتراق

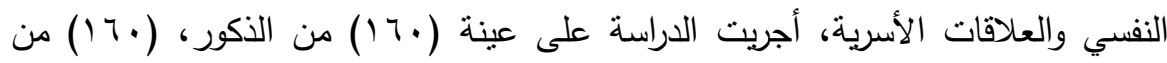
الإناث من الموظفين الإداريين العاملين بالمحاكم، استخدمت الباحثة ثلاثة استخبارات (إثثان من إعدادها وهما استخبار العلاقات الأسرية، الاحتراق النفسي، واستخبار الرضا لإنا الوظيفي للاكتور عويد المشعان ) اعتمدت الدراسة على المنهج الوصفي الارتباطي،

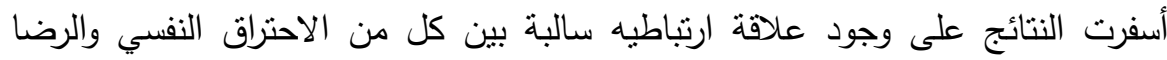
الوظيفي وكذلك الاحتراق النفسي والعلاقات الأسرية، ذلك لدى الموظفين والموظفات، ويزيد هذا لدى الموظفات أثز من الموظفين، توصلت إلى أن الرضا الوظيفي يتوسط العلاقة بين

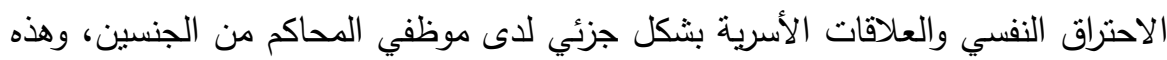

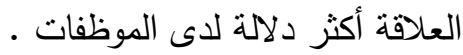

צ - دراسة ( Mojoyinola، 2008 ) بعنوان :"أثر ضغط العمل على الصحة العامة

وعلى السلوك المهني والثخصي للممرضات في المستثفيات العامة في العاصمة ". هدفت الدراسة إلى التعرف على تأثير ضغط العمل على الصحة الجسمية والعقلية والسلوكيات الثخصية والمهنية لعينة من هيئة التمريض بالمستشفيات العامة في العاصمة النيجيرية، طبقت الدراسة على عينة قومها با مفردة من الممرضين، حيث اعتمدت

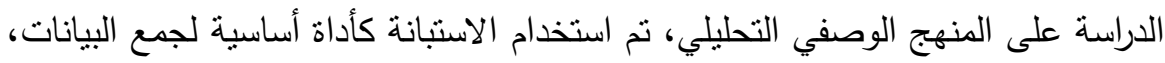
كثفت الدراسة عن وجود علاقة جوهرية بين ضغط العمل والصحة العقلية والجسمية، كما كثفت الدراسة عن وجود فروق جوهرية في السلوكيات الثخصية والمهنية وفقا لمتغير نوع

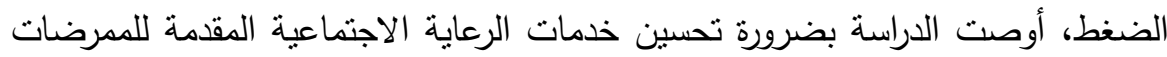

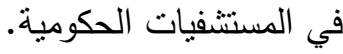


ه- دراسة ( محب عبد اللطيف عبد الباقي، 10 م r ) بعنوان :"الاحترق النفسي وعلاقتّه بالقلق والاكتئاب لاى عينة من المعلمين والمعلمات بالمرطلة الثانوية ".هدفت

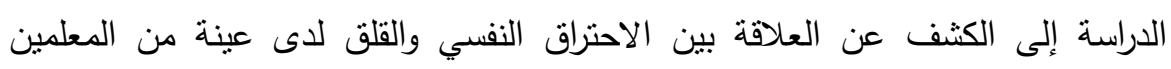

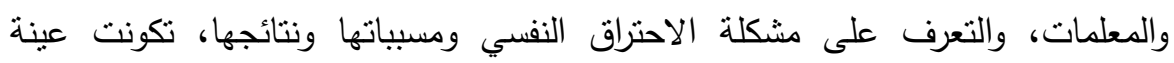

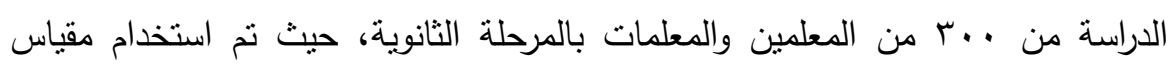

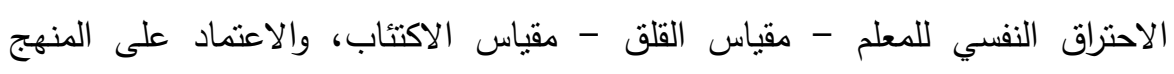

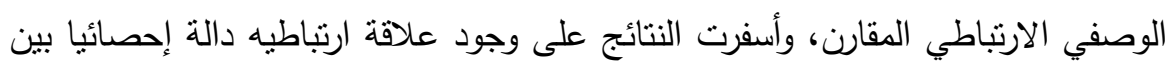

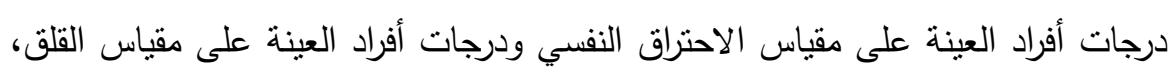

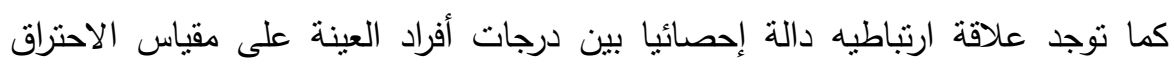
النفسي ودرجات أفراد العينة على مقياس الاكتئاب.

צ- دراسة(kirsi Ahola2008) بعنوان:علاقة الاحتراق النفسي بالأجازات المرضية

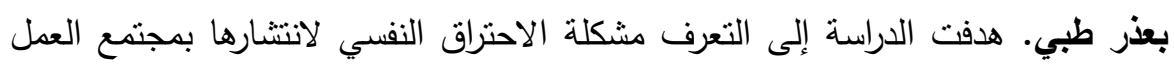

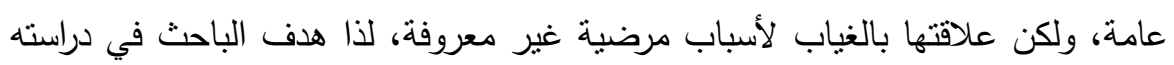

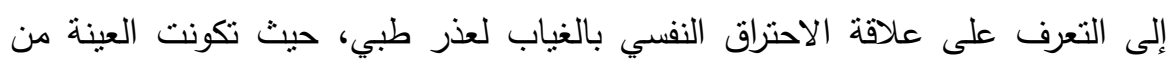

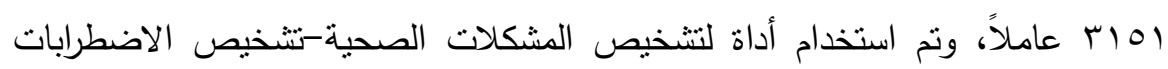

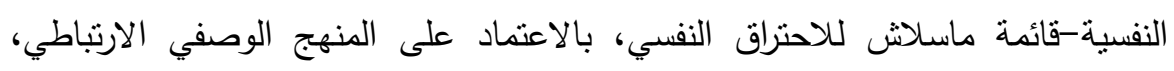

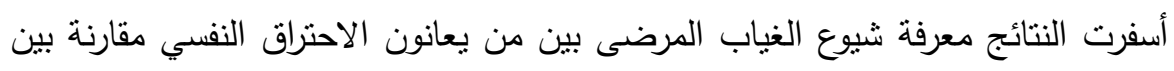

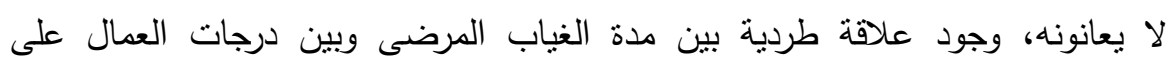

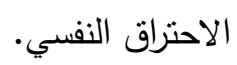

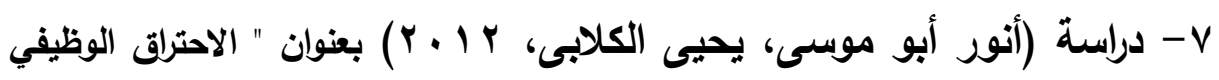
وتأثيره على أداء العاملين: دراسة تطبيقية على الإداريين العاملين فى جمعية إعماء

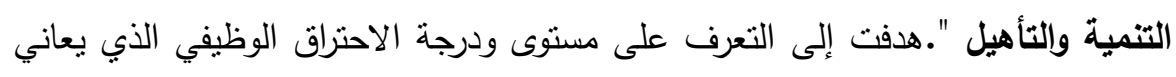

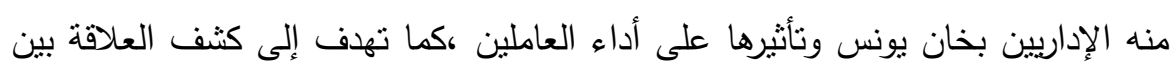

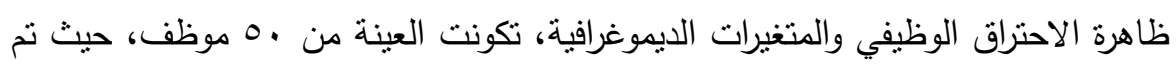

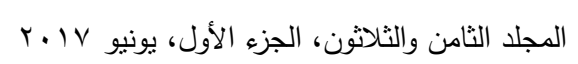


استخدام مقياس ماسلاش للاحتراق الوظيفي، واستخدام المنهج الوصفي الارتباطي، حيث تبين من النتائج أن العاملون يعانون في الوظائف الإدارية بصفة عامة بدرجات منوسطة من الاحتراق الوظيفي في بُعدي(الإجهاد الانفعالي، عدم الإنسانية)، أما على صنى صعيد

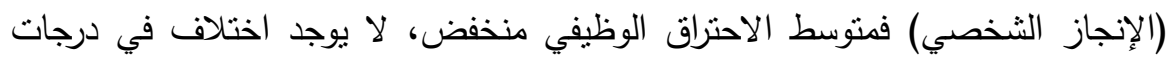

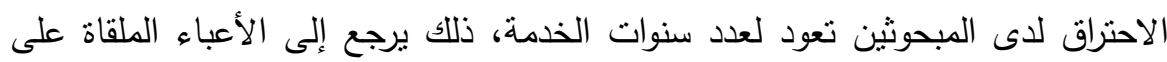
عانقهم سواء قدامى أو جدد.

التعليق العام على الدراسات السابقة: ركزت غالبية الدراسات في أهدافها على الكشف

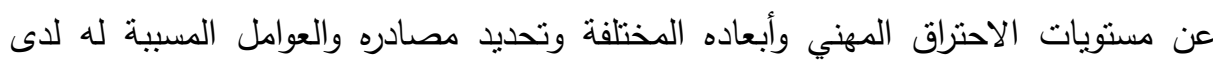
العاملين بالمؤسسات المختلفة، معظم الدراسات استخدمت عينات اعتمدت في معظمها على الطريقة العمدية في الاختيار حيث جرى تحديد العينة من خلال الخصائص المتاحة، العمر، الخبرة في مجال العمل، استخدمت معظم الدراسات الخاصة بالاحتراق المهني لدى العاملين (مقياس الاحتراق النفسي لماسلاش) واستبانه لقياس الضغوط المهنية، كما اعتمدت معظم الدراسات السابقة التي تتاولت الاحتراق المهني لدى الممرضين والممرضات على المنهج الوصفي الارتباطي والوصفي المقارن وذلك بهدف معرفة الفروق والكثف عن العوامل المسببة للاحتراق المهني، بالإضافة إلى نتائج الدراسات التي أسفرت عن وجود علاقة بين بلين الاحتراق النفسي وبعض المتغيرات الأخرى، كما تبين وجود علاقة ارتباطيه بين بيئة العمل والاحتراق

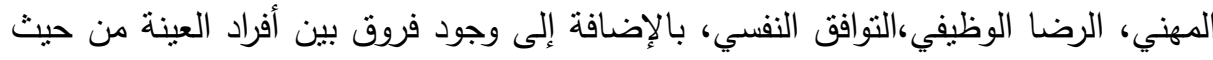

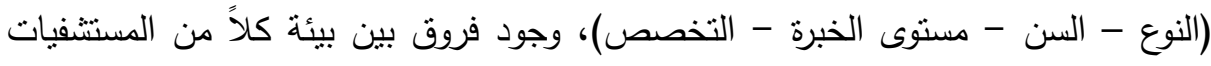
الحكومية والخاصة. 


\section{الإسار اللنظيه}

مفاهيم البحث

أولاً: تعريف الاحترلق المهني: وعرف كذلك بأنه "حالة من الاضطراب والتوتر وعدم الرضا الوظيفي تصيب العاملين في المجال الإنساني والاجتماعي ناتجة من الضغوط النفسية الثديدة

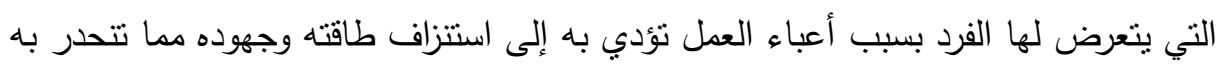

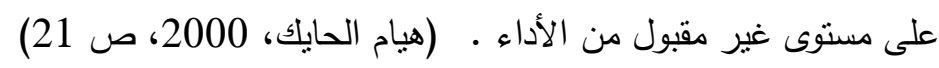

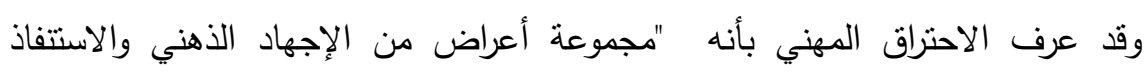
الإنفعالى والتبلد الثخصي والإحساس بعدم الرضا عن المنجز الثخصي والأداء المهني. p 31) 2004)، (Halbesleben ثانيا: تعريف التوافق النفسي: ويعرفه حامد زهران بأنه "عملية دينامية مستمرة تتتاول السلوك

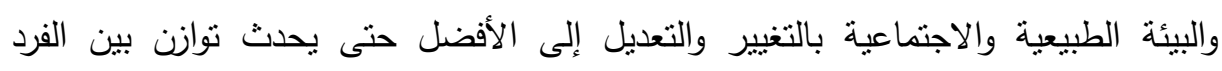

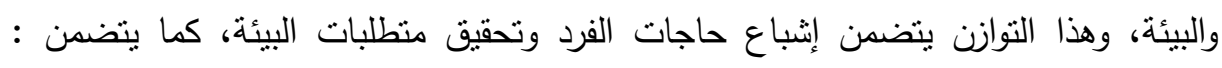

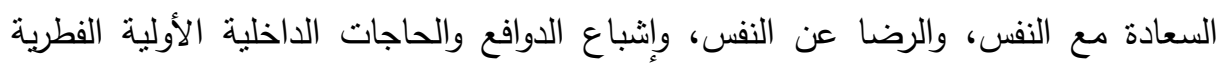

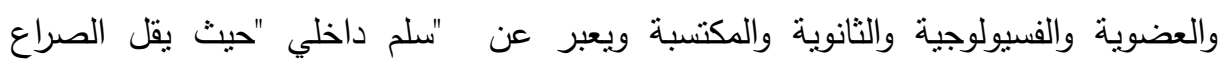

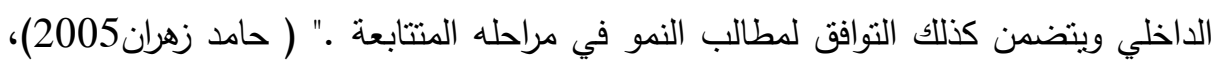

ثالثاً: تعريف التوافق الإجتماعى: يعرفه عبد الفتاح غزال) بأنه الشعور بالسعادة مع الآخرين

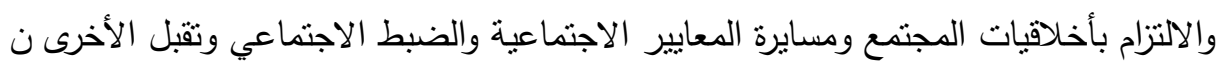
في المجتمع، كما أنه يتأثر بعدة اعتبارات منها:

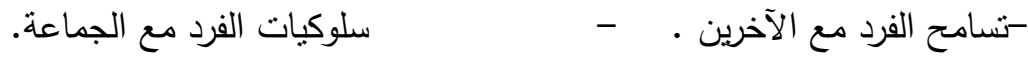

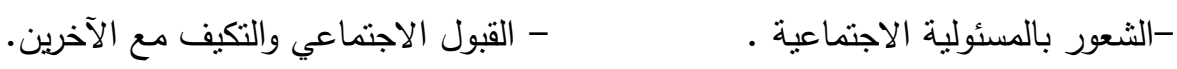

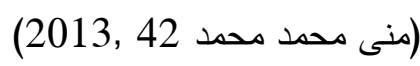

$$
\begin{aligned}
& \text { رابعاً: المستشفيات مندات }
\end{aligned}
$$

المستشفيات الحكومية: وهي التي يتم إدارتها بواسطة جهة حكومية منل وزارة الصحة أو وزارة

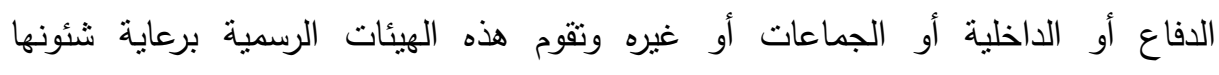


ومصالحها ,وهذا النوع يطبق الأنظمة الحكومية في لوائحها المالية والإدارية ويفترض أن تقدم هذه المستشفيات خدمات صحية لمختلف المواطنين مقابل أجور زهيدة. المستثفيات الخاصة: وتتشل على جميع المستشفيات غير التابعة للحكومة وتقدم خدماتها مقابل رسوم على عكس الحكومية التي من المدكن أن تقدم خدماتها الصحية مجانا أو مقابل فيل فئل

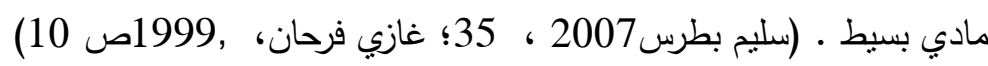

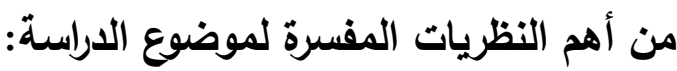
1) نموذج ماسلاش للاحتراق المهني: حيث أثنار هذا النموذج إلى أبعاد الاحتراق التي تم عرضها من قبل والتي نشمل :

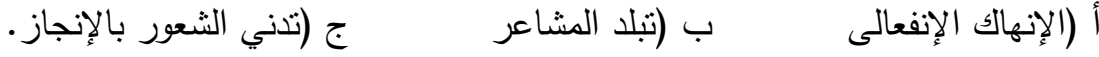

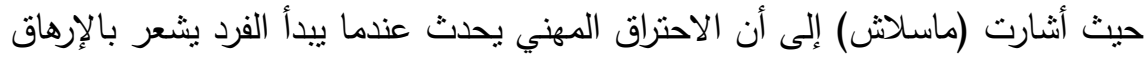
والضعف وفقدان الحيوية والنشاط والإحساس بالعجز عن العطاء ثم يستمر مع تبلد المشاعر وفقدان العنصر الإنساني في التعامل مع الأفراد والثعور باللامبالاة ثم يلي ذلك تقييم الفرد لإنجازاته بطريقه سلبية ويشعر بالانساب وقلة القدرة على الأداء والقيام بالمهام والواجبات

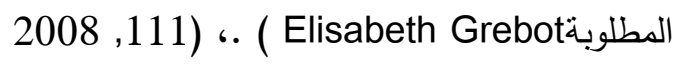
r) النظرية السلوكية: التوافق النفسي عند السلوكيين هو اكتساب الفرد لمجموعة من العادات المناسبة والفعالة في معاملة الآخرين والتي سبق أن تعلهها الفرد، وأدت إلى خفض التى التوتر

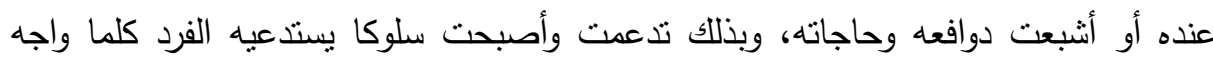

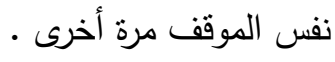

وترى النظرية السلوكية أن السلوك السوي والمتوافق هو حصيلة ما تعلمه الفرد من مواقف تعرض لها، وأن السلوك الذي يخفض التوتر الناتج عن إلحاح الدافع يندعم وبالتالي يتعلمه الفرد ويميل إلى تكراره في المواقف التالية، وعلى حسب عدون لند مرات التدعيم وقدر الإثابة التي مررها يكون نبات السلوك وقوته. (محمود محمد إبراهيم 59 (2002) 


\section{منهجية اللهحث}

أ -منهج البحث: تعد هذه الدراسة من الدراسات الوصفية التي ثقوم على جمع الحقائق وتحليلها وتفسيرها لاستخلاص دلالتها وتصل بذلك لإصدار التعميمات بشأن الظاهرة

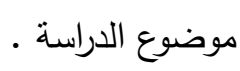

وقد استخدم الباحثون (المنهج الوصفي المقارن) وذللك لملائمته موضوع الدراسة، وفي

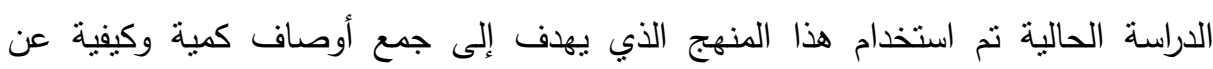
الظاهرة المدروسة كما تحدث في وضعها الطبيعي. ب -عينة البحث: اختيرت عينة النطبيق بالطريقة العشوائية) وقد اشتثلت عينة التطبيق

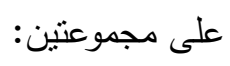

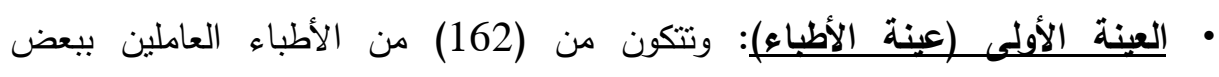
المستشفيات الحكومية، عدد (127) من الأطباء العاملين ببعض المستشفيات الخاصنة.

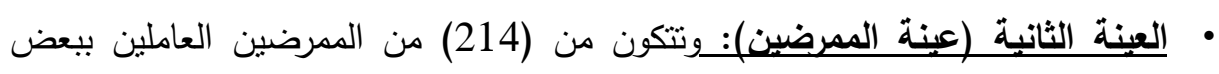
المستشفيات الحكومية، وعدد (103) من الممرضين العاملين بالمسنتفيات الخاصة. ج -أدوات البحث: ضمت الأدوات المستخدمة في الدراسة الراهنة على ما يلي: • • مقياس الاحتراق المهني للأطباء. (إعداد الباحث) • مقياس الاحتراق المهني للممرضين. (إعداد الباحث)

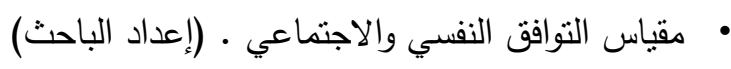

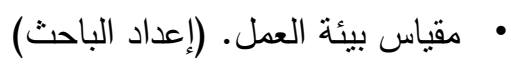

وقد نم اختيار هذه الأدوات حتى تتلاعم مع طبيعة الدراسة ولكي يتم التحقق من الفروض

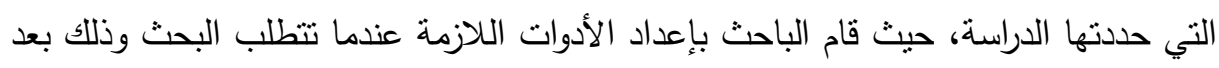
التأكد من صحة ثباتها وصدقها، كما تم حساب ثبات وصدق المقاييس التي أعدها الباحث. وفيما يلي عرض لاختبار ثبات وصدق الأدوات: المحور الأول: ثبات وصدق مقياس الاحترلق المهني للأطباء: (إعداد الباحث): قد قام الأبات

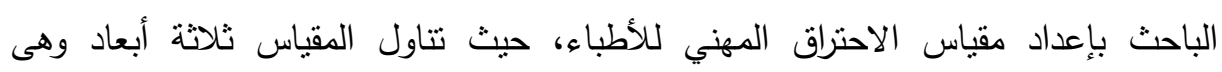


(الإجهاد الإنفعالى، تبلد المشاعر، انخفاض الإنجاز الثخصي)، يحتوى على (45) عبارة، بحيث يدلى الأطباء استجاباتهم وفقاً للاختيارات (دائماً / أحياناً/ نادراً /أبداً). ا ـ بالنسبة لحساب الثبات: للتحقق من ثبات المقياس لإمكانية الاعتماد على نتائج المقاييس

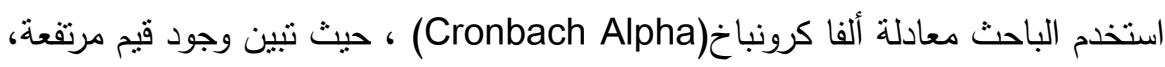
وتثير هذه القيم من معاملات الثبات إلى صلاحية العبارات وإمكانية الاعتماد على نتائجها والوثوق بها.

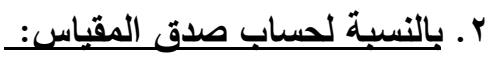

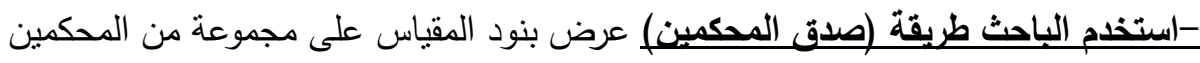
الخبراء في مجال علم النفس والصحة النفسية والقياس النفسي، للتأكد من مدى ملائمة أبعاد عبارات المقياس لما وضع لقياسه بالنسبة لفئة الأطباء.

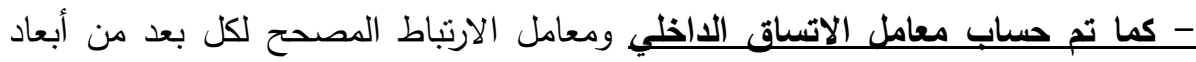

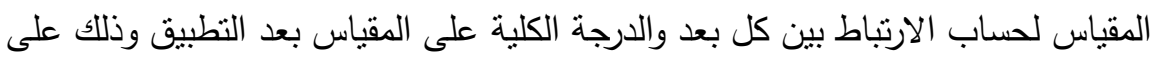
عينة من الأطباء وقد جاءت النتائج كالتالي: حيث قام الباحث بحساب معامل الارتباط

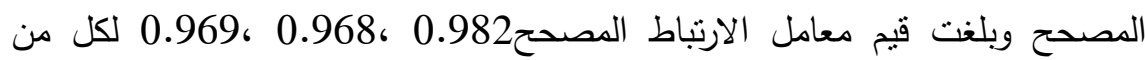
الإجهاد الإنفعالى، تبلا المشاعر، انخفاض الإنجاز الثخصي (على النوالي، وهي قيم تؤكد على صدق أبعاد مقياس الاحتراق المهني للأطباء. المحور الثاني: ثبات وصدق مقياس الاحتراق المهني للممرضين: (إعداد الباحث): قد قام الباحث بإعداد مقياس الاحتراق المهني للأطباء، حيث تتاول المقياس ثلاثة أبعاد وهى الإنى (الإجهاد الإنفعالى، تبلا المشاعر، انخفاض الإنجاز الثخصي)، يحتوى على (45) عبارة، بحيث يدلى الأطباء استجاباتهم وفقاً للاختيارات (دائماً / أحياناً/ نادراً /أبداً). ا ـ بالنسبة لحساب الثبات: للتحقق من ثبات المقياس لإمكانية الاعتماد على نتائج المقاييس

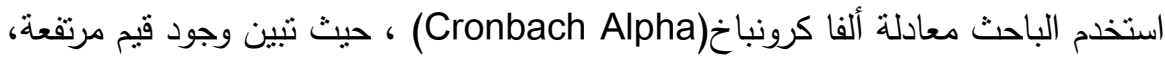

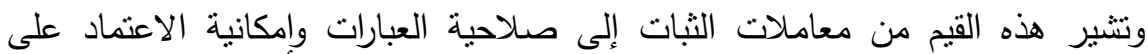
نتائجها والوثوق بها. 
r r بالنسبة لحساب الصدق:

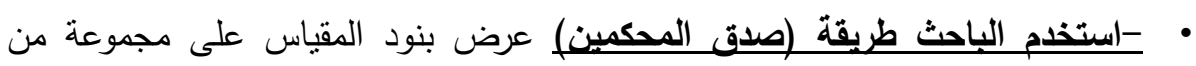

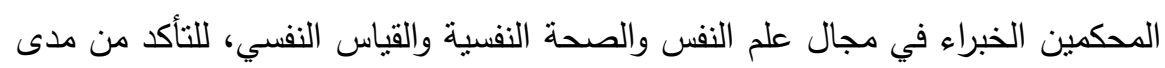

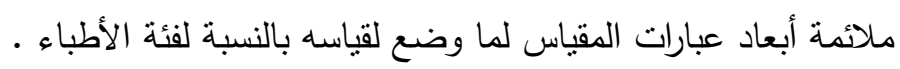

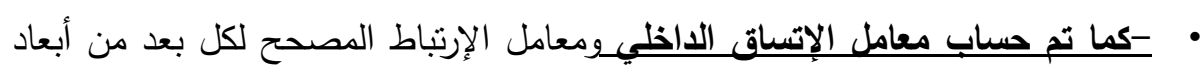

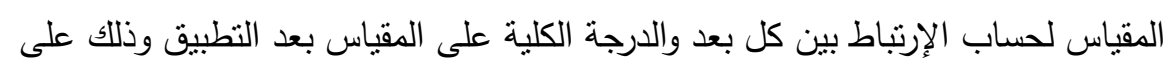
عينة من الأطباء وقد جاءت النتائج كالتالي : حيث قام الباحث بحساب معامل الارتباط

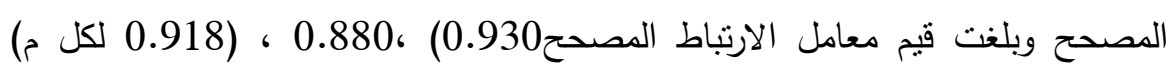
الإجهاد الإنفعالى، تبلد الشاعر، انخفاض الإنجاز الثخصي (على التوالي، وهي قيم تؤكد على صدق أبعاد مقياس الاحتراق المهني للممرضين.

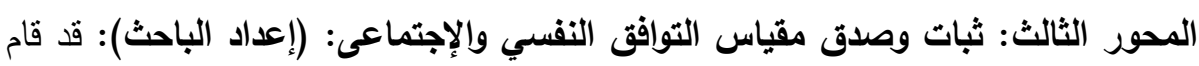

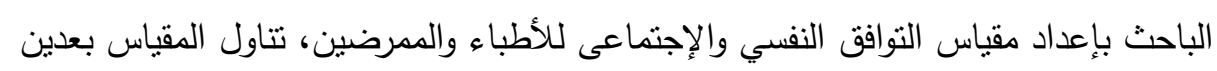
وهما النوافق النفسي، النوافق الإجتماعى (كل بعد يحتوى على (30) عبارة ) حتى يصبح مجموع عبارات المقياس (60) عبارة، بحيث يدلى الأطباء والممرضين استجاباتهم وفقاً للاختيارات (دائماً / أحياناً / أبداً).

1. بالنسبة لحساب الثبات: للتحقق من ثنات المقياس لإمكانية الاعتماد على نتائج المقاييس

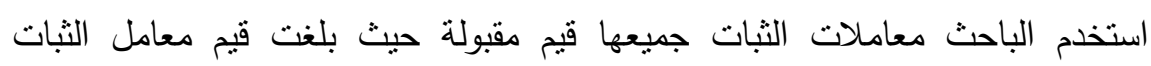

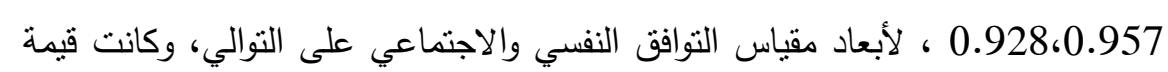
ألفا لإجمالي مقياس التوافق النفسي والاجتماعي (0.970) وهي قيمة مرتفعة، ونتشير هذه ولهي

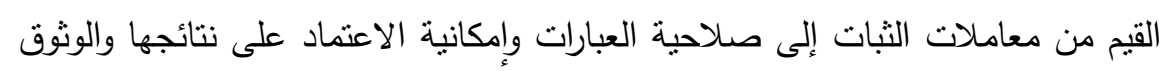

$$
\text { بها. }
$$

\section{r • بالنسبة لحساب الصدق:}

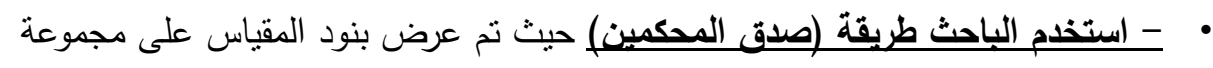

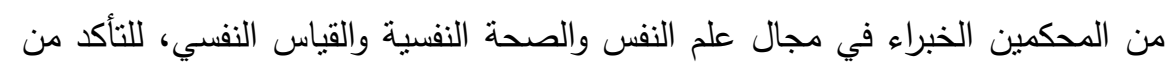

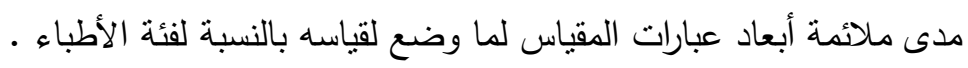

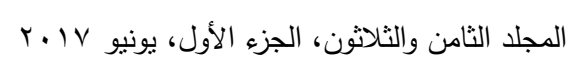


• - كما تم حساب معامل الإتساق الداخلي_ومعامل الإرتباط المصحح لكل بعد من أبعاد المقياس لحساب الإرتباط بين كل بعد والدرجة الكلية على المقياس بعد النطبيق وذللك على الإنى عينة من الأطباء وقد جاءت النتائج كالتالي: حيث قام الباحث بحساب معامل الارتباط

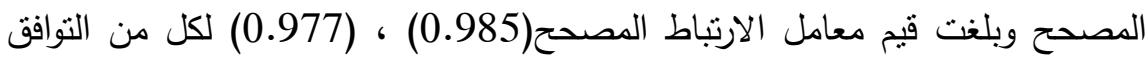
النفسي، النوافق الاجتماعي على التوالي، وهي قيم تؤكد على صدق أبعاد مقياس التوافق

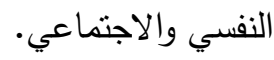
المحور الرابع: ثبات وصدق مقياس بيئة العمل( إعداد الباحث): قد قام الباحث بإعداد مقياس بيئة العمل الخاصة بالمستشفيات وذللك ليشمل جميع أفراد العينة من الأطباء والممرضين، حيث يحتوى المقياس على عدد (45)، بحيث يدلى الأطباء والممرضين استجاباتهم وفقاً للاختيارات (دائماً / أحياناً / أبداً). ا ـ بالنسبة لحساب الثبات: أ- حساب الثبات باستخدام معادلة ألفا كرونباخ:

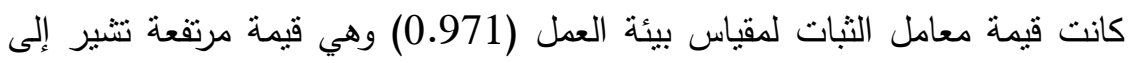
صلاحية العبارات وامكانية الاعنماد على نتائجها والوثنوق بها.

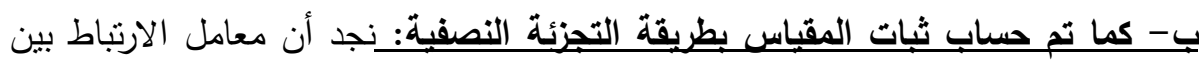
مجموعة العبارات الفردية وإجمالي المقياس دالة معنوياً عند مستوى معنوية(0.05) ، و معامل

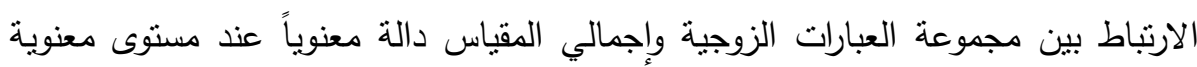
(0.05)مما يؤكد على ثبات مقياس بيئة العمل، حيث قام الباحث بحساب معامل الارتباط المصحح وبلغت قيم معامل الارتباط المصحح0.985 ، 0.9770كل من العبارات الفردية، العبارات الزوجية على التوالي، وهي قيم تؤكد على ثبات المقياس. r r بالنسبة لحساب صدق مقياس بيئة العمل: أ- استخدم الباحث طريقة (صدق المحكمين) حيث تم عرض بنود المقياس على مجموعة من بلن

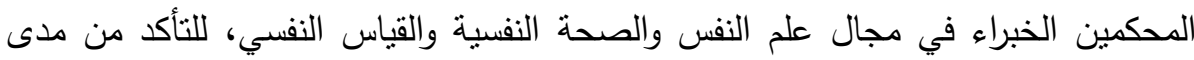
ملاءمة أبعاد عبارات المقياس لما وضع لقياسه بالنسبة لفئة الأطباء والممرضين. 


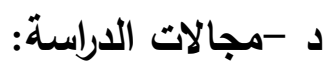

-المجال المكاني: قد تم إجراء الدراسة الميدانية ببعض المستشفيات الحكومية وتتثل (مستشفى185القصر العيني للحوادث والحروق) التابعة مستشفيات جامعة القاهرة ، (مستثفى لمراء أمراض وجراحات القلب والأوعية الدموية، مستشفى النساء والتوليد، مستشفى الأطفال، مسنتفى الباطنة، مستشفى الجراحة - الدمرداش، مركز علاج الأورام والطب النووي، مركز

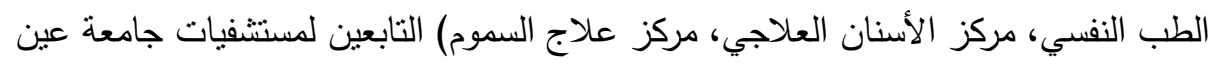

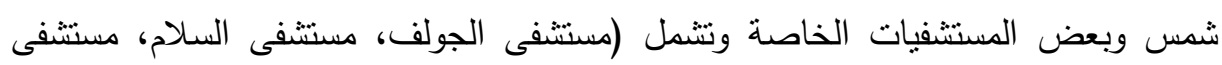
القتح، مستشفى روكسى ) ) -المجال البشرى: العينة الأولى: تكونت من (289) من الأطباء( العاملين بالمستشفيات وانقسمت (162) ممن يعملون بالمستشفيات الحكومية، (127) ممن يعملون بالمستشفيات

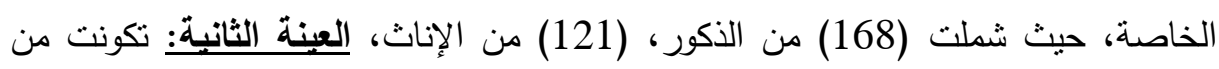

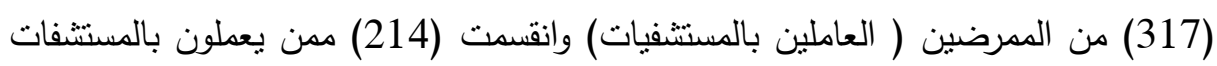

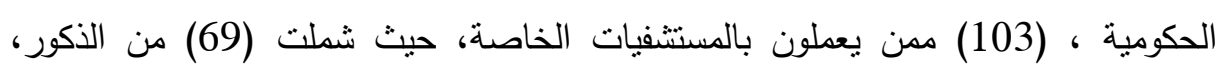
(248) من الإناث.

-المجال الزمني: مرت الدراسة بعدة مراحل في الفترات الزمنية الآتية :

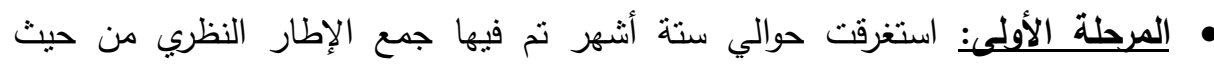

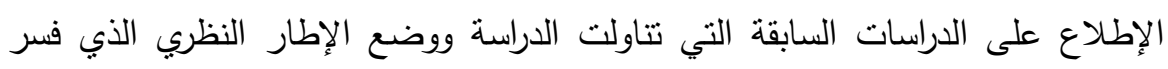
مشكلة الدراسة والنظريات الموجهة لها. • المرحلة الثانبة: استغرقت حوالي شهرين واشتملت على إعداد الأدوات وعرض المقاييس

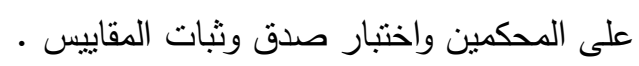
•المرحلة الثالثة: عمل الدراسة الاسنطلاعية وتطبيق المقاييس، استغرق التطبيق العملي

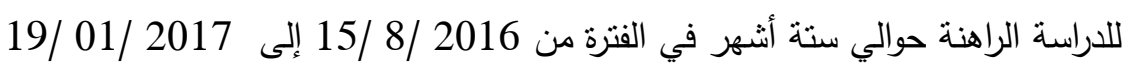
• المرحلة الرابعة: استمرت حوالي شهر ونصف فيها نم تفريغ البيانات وتحليل النتائج وتفسيرها، ووضع نوصيات ومقترحات الدراسة. 


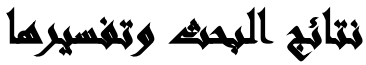

الفرض الأول: نوجد علاقة ارتباطية ذات دلالة إحصائية بين درجات الاحتراق المهني والتوافق النفسي لاى الأطباء.

جدول(1): العلاقة الارتباطية بين الاحتراق المهني والتوافق النفسي لاءى الأطباء

\begin{tabular}{|c|c|c|c|}
\hline ألالاله المفوبرة & 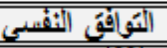 & & ابعاد الاحترلقِ المهنْئ \\
\hline$\ldots \ldots$ & $-. . A 1 \times-1$ & معامل اربَّباط & الإجهاد الاثفعالّي \\
\hline .... &..$- A A r^{(-2)}$ & معامل اربَباط & تبَلد المثُّاعز \\
\hline .... &.$- .111^{(-2)}$ & معامل اربَباط & اتخفاض الإتجاز المُخْصى \\
\hline$\ldots \ldots$ &..$- A v v^{(-0)}$ & معامل اربَّباط & جمالى مقِياس الاحترلق المهنْ \\
\hline
\end{tabular}

يتضح من الجدول السابق للعلاقة الارتباطية بين الاحتراق المهني والتوافق النفسي لدى الدي الأطباء يتضح التالي: • توجد علاقة عكسية ذات دلالة إحصائية عند مستوى معنوية (0.05)بين الإجهاد

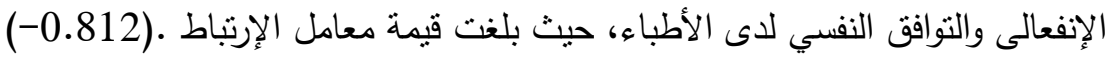

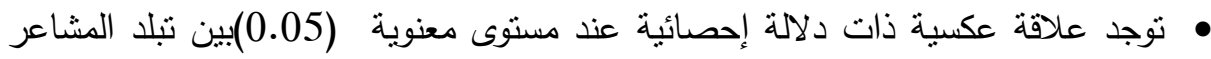

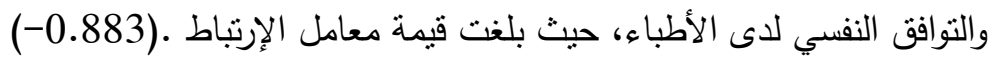

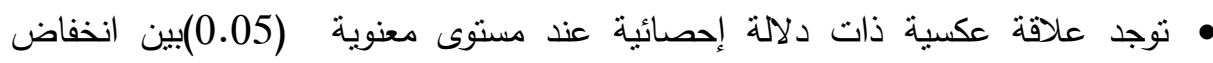

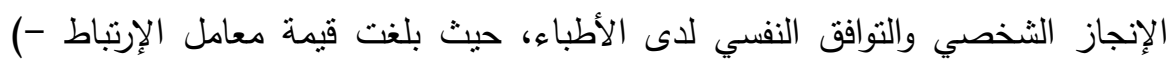
• توجد علاقة عكسية ذات دلالة إحصائية عند مستوى معنوية (0.05)بين إجمالي مقياس

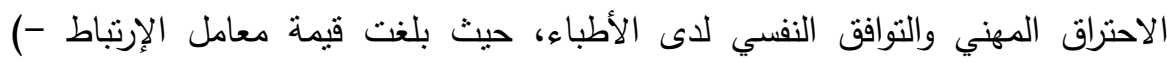
0.877). لذا يثبت صحة الفرض الأول :توجد علاقة ارتباطية ذات دلالة إحصائية بين درجات الاحتراق المهني والنوافق النفسي لدى الأطباء. من حيث البعد الأول: أن زيادة معدل الإجهاد الانفعالي من حيث كثرة الأعباء التي تقع على الاهي الني

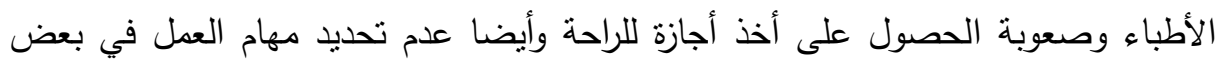

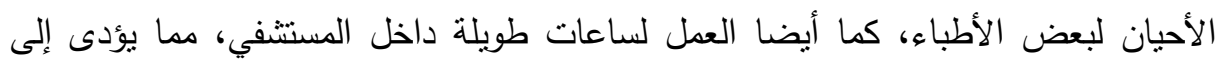
300 المجلد الثامن والثلاثثن، الجزء الأول، يونيو Y Y Y r 
زيادة الإجهاد الانفعالي لديهم فالأطباء بذلك قد يشعرون مع هذا الإجهاد بالغضب حتى

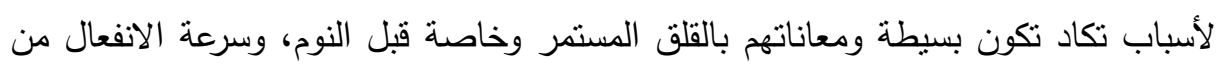
المواقف التي تحدث نتيجة تعاملهم مع المرضى بطريقة مباشرة فذللك يؤدى إلى سوء التوافق بقانق النفسي لديهم.

ومن حيث تبلا المشاعر : للدى معظم الأطباء أفراد العينة فيتضح من الجدول ارتفاع نسبة

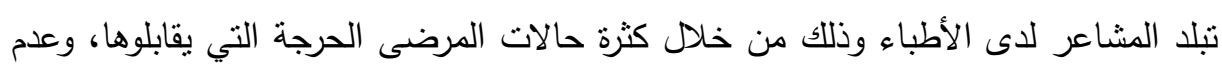

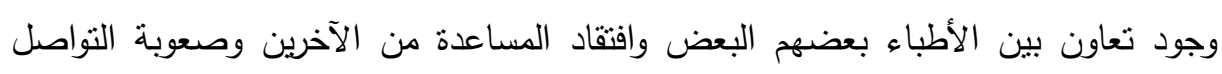

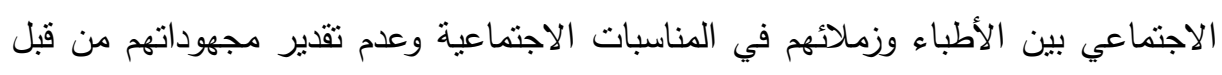

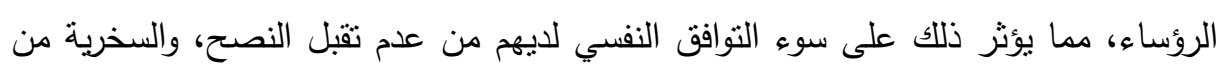

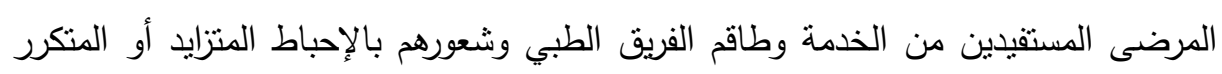
في حياتهم العلمية أو المنية. من حيث البعد الثالث: نتيجة أن الأطباء أحيانا يكونون غير راضيين عن انجازاتهم في عملهم

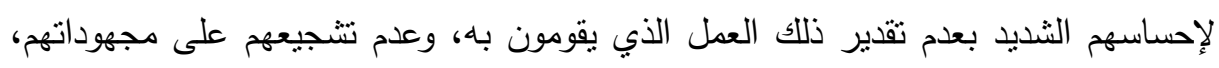
وأيضا صعوبة الحصول على دورات علمية لتحسين وضعهم المهني وعمل الأبحاث اللازمة لتحسين أداء العمل، وقلة التدريب المستمر مما يؤدى إلى قلة التطوير في عملهم وبالتالي

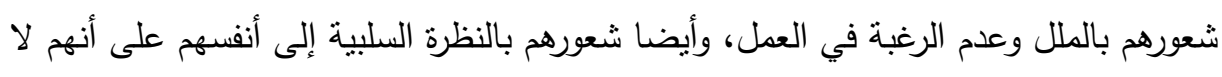

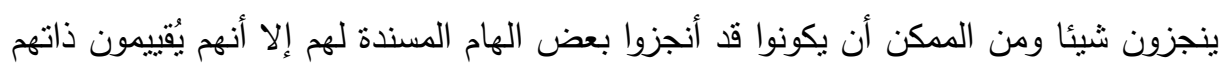

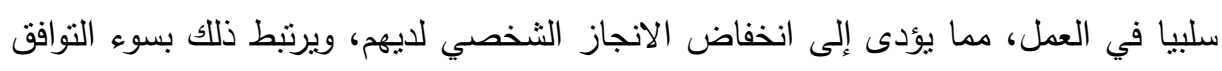

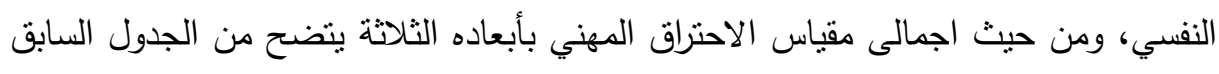

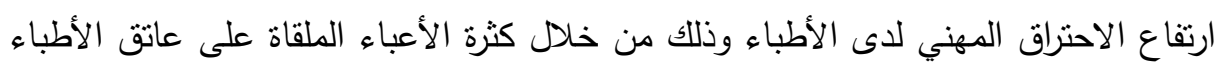

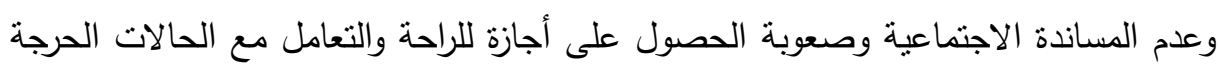

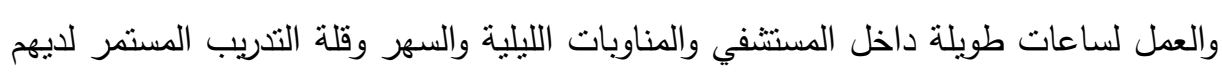
وبالتالي يؤثز ذلك على سوء التوافق النفسي فإن الأطباء نتيجة لمدى التعرض الثنديد للاحتراق

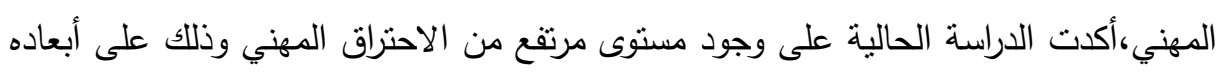

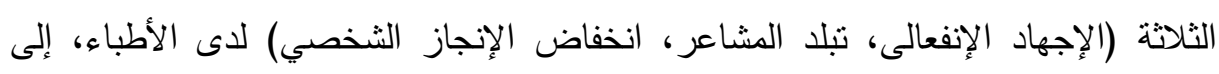

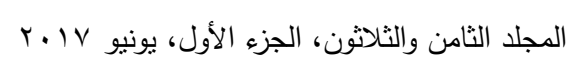


جانب وجود علاقة ذات دلالة إحصائية بين درجات الاحتراق والنتافق النفسي وذلك ما أكدته نتيجة دراسة (السيد مصطفي راغب، ^ • . Y) من حيث وجود ارتباط دال بين درجات الاحتراق النفسي وأبعاد الإنهاك الإنفعالى وانخفاض قيمة العمل وبين الدرجة الكلية لضغوط العمل

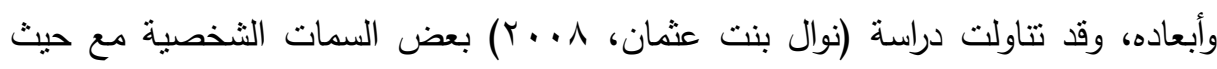

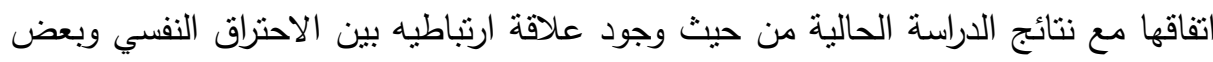
سمات الثخصية (الثبات الإنفعالى)، إلى جانب (نموذج ماسلاش للاحتراق المهني) الذي ركز على أبعاد الاحتراق المهني من حيث التسلسل في الأعراض التي يظهر لدى الأفراد ممن الته

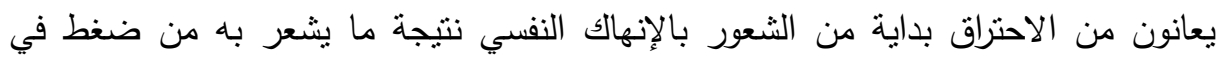
العمل ويظهر عليه الإرهاق وبعض الأعراض الجسمية.، النظريات التي تؤكد أيضا على بلى لإنه

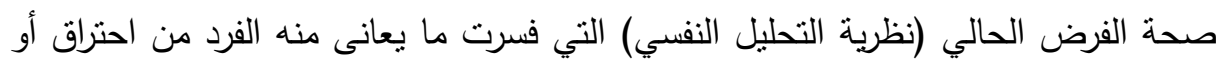

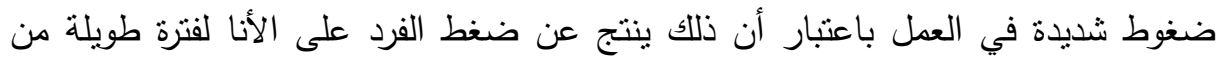
الزمن حتى يصبح أكثر كفاءة في عمله ويهنت بمهامه الموكلة إليه مما قد يشكل جهداً مستمراً وإنهاكا لجسده وصحته النفسية ومع عدم قدرته على مواجهة هذه الضغوط شديدة بشكل سوى أو يقوم بكبت نللك الرغبات التي تتعارض مع مكونات الثخصية ينتج عنه صراع بين هذه

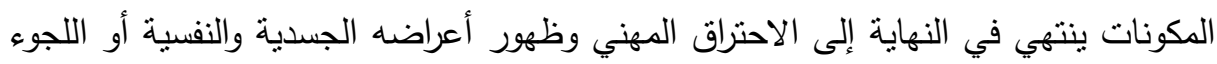

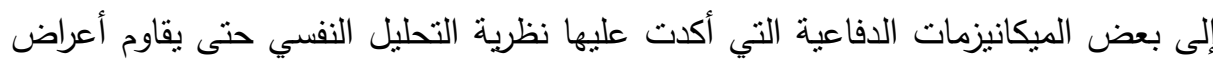
الاحتراق المني منل التفريغ النفسي الذي يقوم به. الفرض الثاني: توجد علاقة ارتباطيه ذات دلالة إحصائية بين درجات الاحتراق المهني والتوافق الاجتماعي لاى الأطباء. جدول(ץ): العلاقة الارتباطية بين الاحتراق المهني والتوافق الاجتماعي لدى الأطباء

\begin{tabular}{|c|c|c|c|}
\hline & المَوافقتى الاجنماعى & & أبعاد الاحترلق المهني \\
\hline$\ldots \ldots$ & $-\cdot \cdot v \cdot \neg(* *)$ & معامل ارتباط & الإجهاد الإتفعالّى \\
\hline$\ldots \ldots$ &.$-+ \vee \wedge \cdot(* *)$ & معامل ارتباط & تبلد المشُاعز \\
\hline$\ldots \ldots$ &..$- V \varepsilon Y\left({ }^{* *}\right)$ & معامل ارنباط & انخفاض الإتجاز الشخصى \\
\hline$\ldots \ldots$ &..$- \vee \vee q(* *)$ & معامل ارتباط & 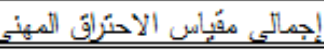 \\
\hline
\end{tabular}


يتضح من الجدول السابق للعلاقة الارتباطية بين الاحتراق المهني والثوافق الاجتماعي

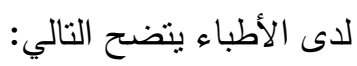
• توجد علاقة عكسية ذات دلالة إحصائية عند مستوى معنوية (0.05)بين الإجهاد

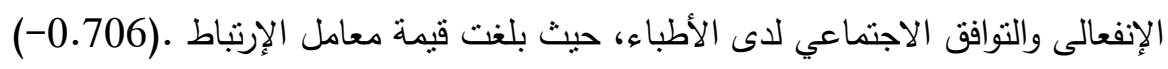

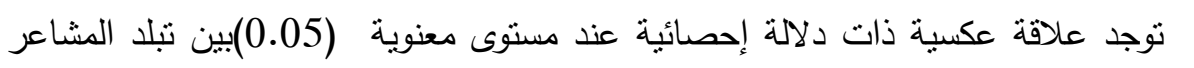

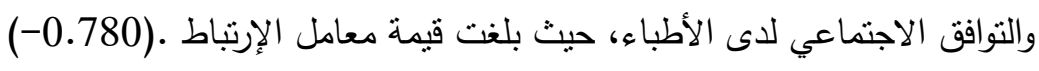

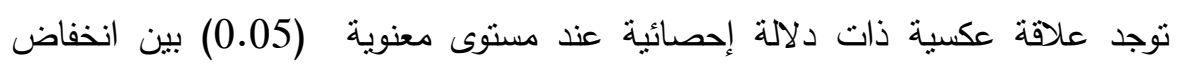

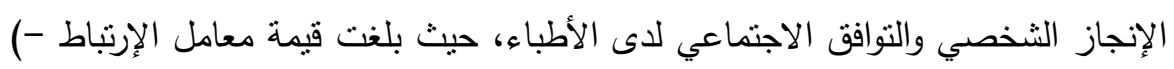

توجد علاقة عكسية ذات دلالة إحصائية عند مستوى معنوية (0.05)بين إجمالي مقياس

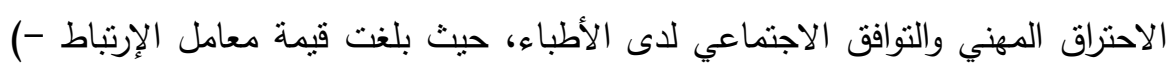

لذا يثبت صحة الفرض الثاني :توجد علاقة ارتباطية ذات دلالة إحصائية بين درجات الاحتراق المهني والثوافق الاجتماعي لاى الأطباء.

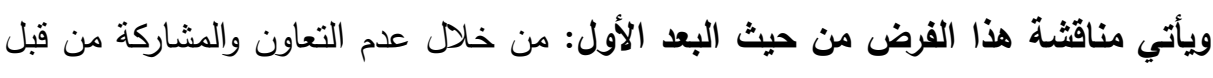

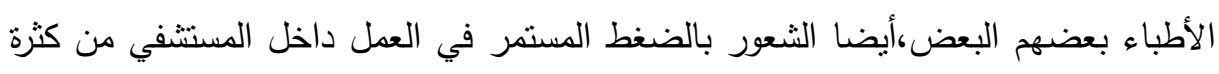

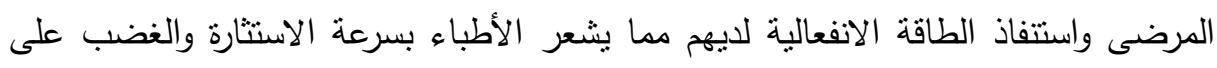

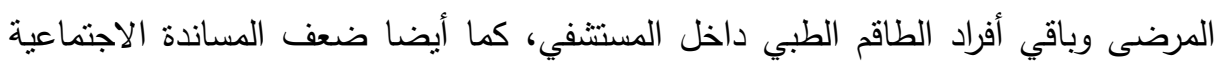

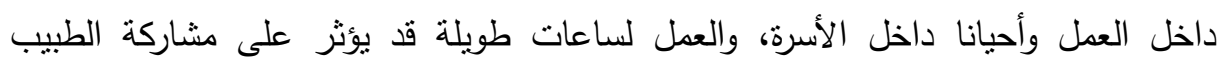

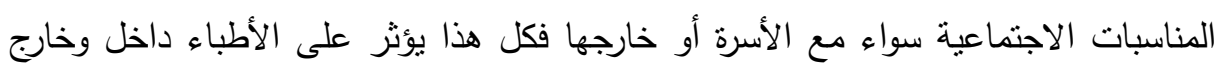

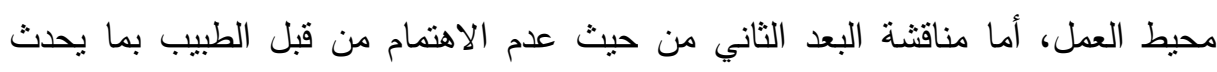

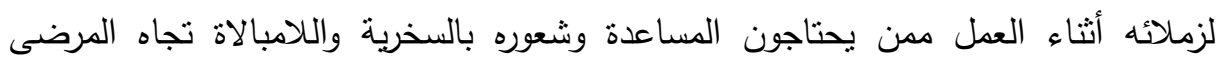

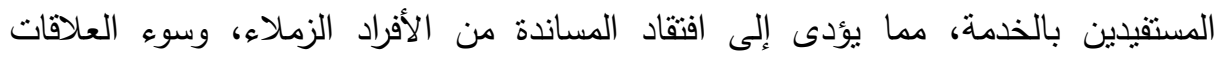

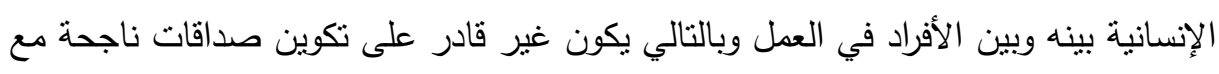

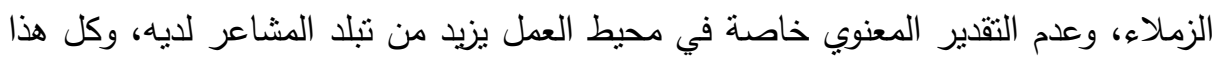

$$
\text { المجلد الثامن والثلاثون، الجزء الأول، يونيو Y. V }
$$


يؤثر على التوافق الاجتماعي سواء على مستوى العمل أو خارجه أو في محيط الأسرة، أما البعد الثالث وذللك لأن معظم الأطباء أفراد العينة كانوا قد يشعرون بأنهم لديهم طاقة وحيوية الثية ونشاط داخل العمل إلا أنهم لا يجيدون فرص للتطوير في مجال العمل وبعضهم تكون

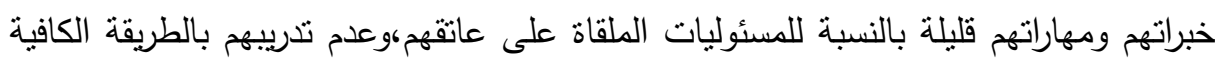

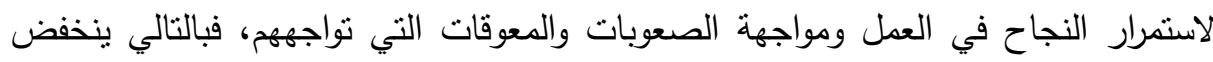
أدائهم في العمل ويؤثر ذلك على التوافق الاجتماعي لديهر من حيث تجنب العمل الجماعي أو وأو

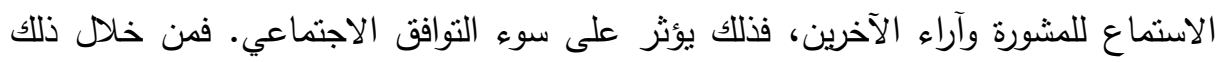

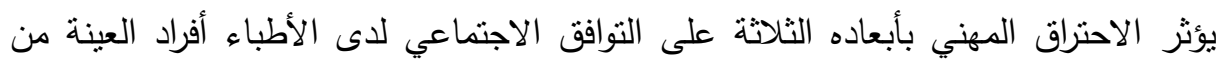

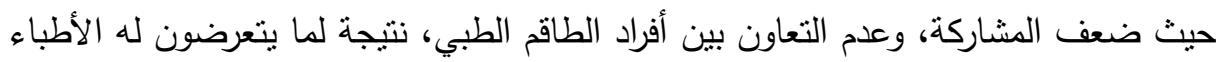
من ضغوط مهنية شديدة تصل بهم إلى درجة الاحتراق المهني فيؤثز ذلك على توافقهم الاجتماعي سواء داخل العمل أو خارجه. تتفق هذه النتيجة مع دراسة ( Magdlena) Muszalska العمل لاى الأطباء، وكثفت نتائجها عن أن الضغوط اليومية التي يتعرض لها الأطباء نؤثر

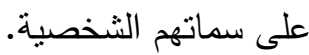
الفرض الثالث: نوجد علاقة ارتباطية ذات دلالة إحصائية بين درجات الاحتراق المهني والتوافق النفسي لدى الممرضين. جدول(َ):العلاقة الارتباطية بين الاحتراق المهني والتوافق النفسي لدى الممرضين

\begin{tabular}{|c|c|c|c|}
\hline الدلالة المغويرة & التُوافقي الثفسى & & أبعاد الاحترلق المهني \\
\hline$\ldots$ &..$- \vee \operatorname{Tr}(* *)$ & معامل ارتباط & الإجهاد الإنفعالّي \\
\hline$\ldots$. &.$- .0\{\wedge(* *)$ & معامل ارتباط & 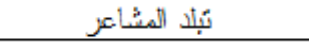 \\
\hline$\ldots \cdot$ &.$\left.- .7 \varepsilon 0^{* *}\right)$ & معانمل ارتباط & انخفاض الإتجاز الشخصى \\
\hline$\ldots \ldots$ &..$- \vee \wedge \vee(* *)$ & معأمل ارتباط & إجمالي معُباس الاحتراقي المهن \\
\hline
\end{tabular}


يتضح من الجدول السابق للعلاقة الارتباطية بين الاحتراق المهني والتوافق النفسي لدى

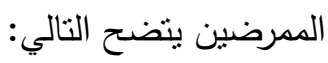
• توجد علاقة عكسية ذات دلالة إحصائية عند مستوى معنوية (0.05)بين الإجهاد

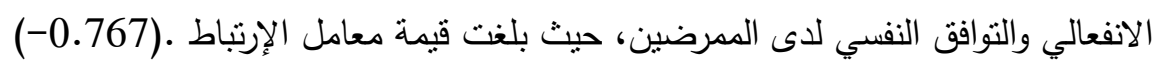

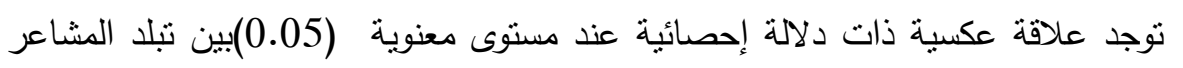

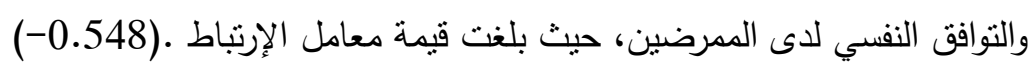

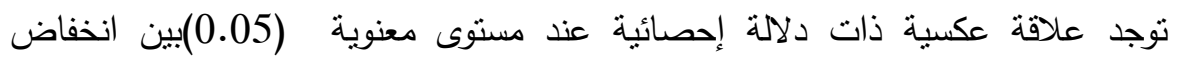

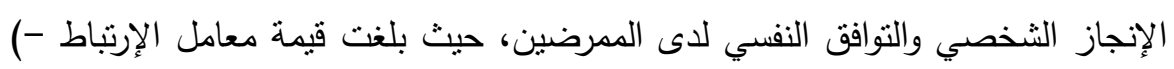

توجد علاقة عكسية ذات دلالة إحصائية عند مستوى معنوية (0.05)بين إجمالي مقياس

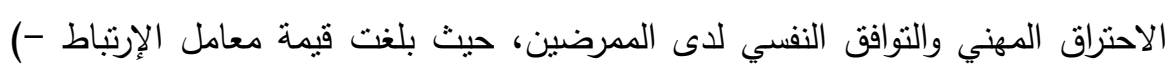

لذا يثبت صحة الفرض الرابع :توجد علاقة ارتباطية ذات دلالة إحصائية بين درجات الاحتراق المهني والتوافق النفسي لدى الممرضين.

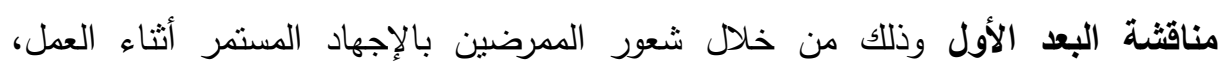
والتعرض المباشر للضغوط من قبل المرضى من حيث عدم احترام سياسة القسم لأوقات

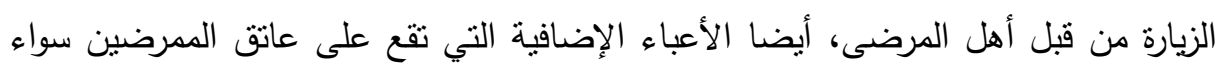

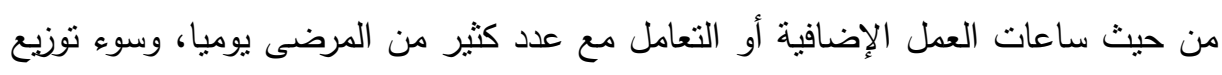

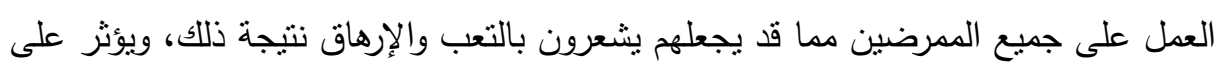

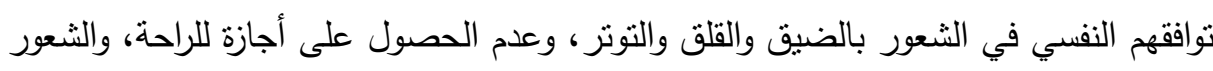

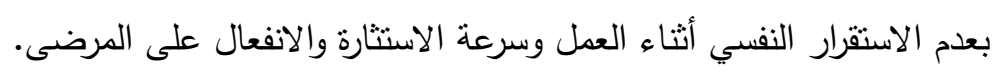

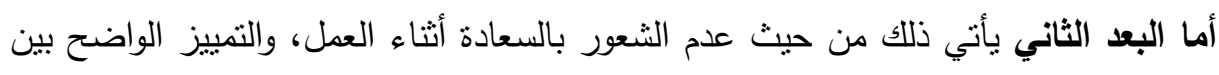

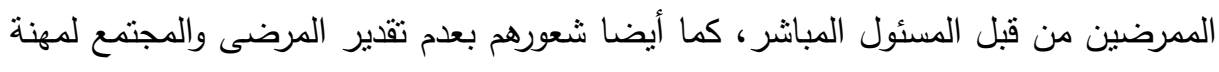

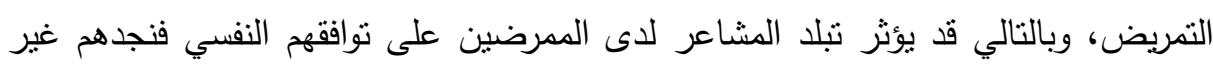


قادرين على تأدية العمل المطلوب أو المكلف منهم على أكمل وجه يليق بتقديم الخدمة للمرضى وشعورهم بالتوتر والقلق.

والبعد الثالث حيث شعور الممرضين بصعوبة الوصول لأهدافهم وعدم النطور فيما يقومون به

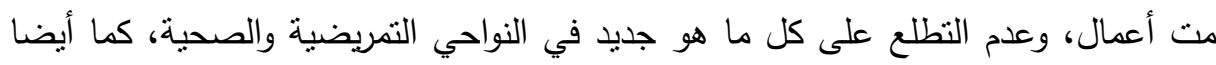

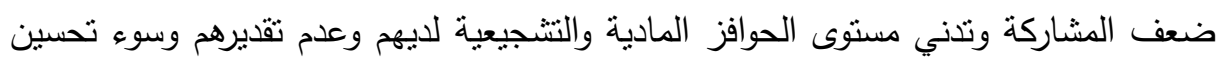

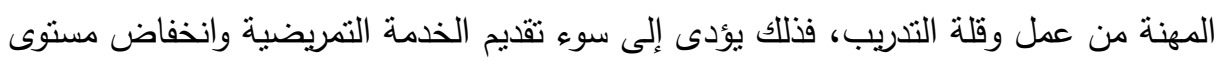
الأداء في العمل ويؤثر على النوافق النفسي لديهم من نظرتهم النفسية لأنفسهم بأنهم أصبحوا

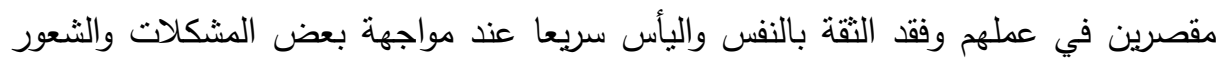

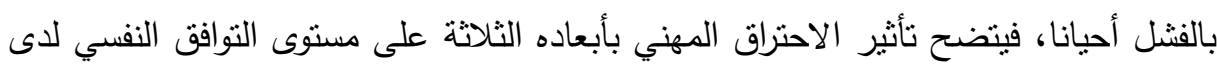

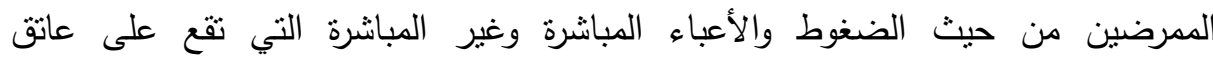

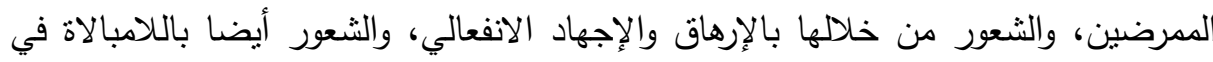
العمل وسوء تقديم الخدمة للمرضى والسخرية من المستقيدين من الخدمة التمريضية، وبالتالي انخفاض الانجاز الثخصي لديهر، وكل هذا له تأثير قوى ومباشر على التوافق النفسي لديهر. الفرض الرابع :توجد علاقة ارتباطية ذات دلالة إحصائية بين درجات الاحتراق المهني والتوافق الاجتماعي لاى المرضين. جدول(؛): العلاقة الارتباطية بين الاحتراق المهني والتوافق الاجنماعي لدى الممرضين

\begin{tabular}{|c|c|c|c|}
\hline الالالية المثوبية & 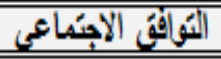 & & 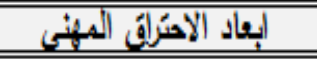 \\
\hline$+\ldots$ &.$- .719(\% *)$ & معامل ارئاط & 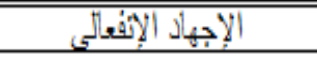 \\
\hline$\ldots$ & $-. . \Gamma+.(* *)$ & معامل ارنباط & تُبلد المشاعز \\
\hline$\ldots$ & $-., 0 \mathrm{~V},(* *)$ & معامل ارنباط & انخفاض الإتجاز الشُخصى \\
\hline 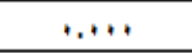 &.,$- 7 \cdot \Gamma(\%)$ & معامل ازئباط & 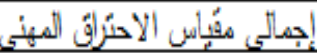 \\
\hline
\end{tabular}

يتضح من الجدول السابق للعلاقة الارتباطية بين الاحتراق المهني والتوافق الاجتماعي

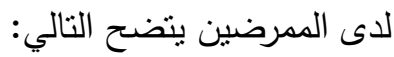


• توجد علاقة عكسية ذات دلالة إحصائية عند مسنوى معنوية (0.05)بين الإجهاد

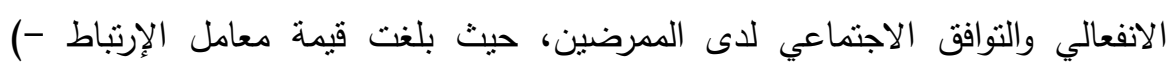

توجد علاقة عكسية ذات دلالة إحصائية عند مستوى معنوية (0.05)بين تبلد المشاعر

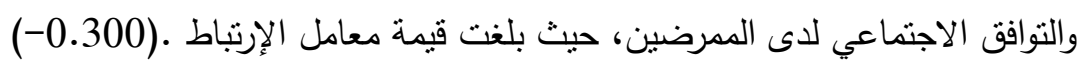

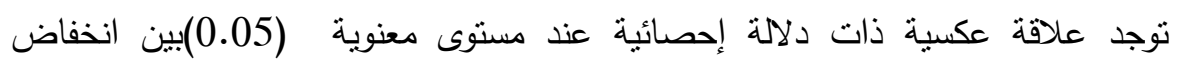

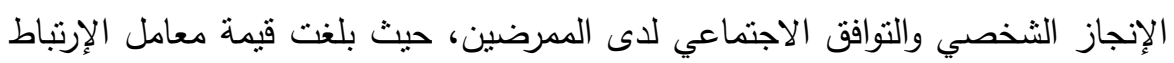
$(-0.570)$.

توجد علاقة عكسية ذات دلالة إحصائية عند مستوى معنوية (0.05)بين إجمالي مقياس

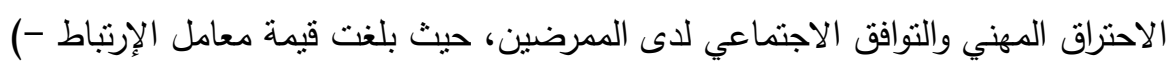

$$
0.603) \text {. }
$$

لذا يثبت صحة الفرض الرابع :توجد علاقة ارتباطية ذات دلالة إحصائية بين درجات

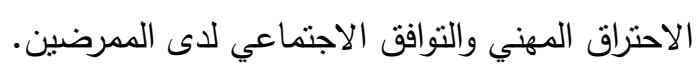

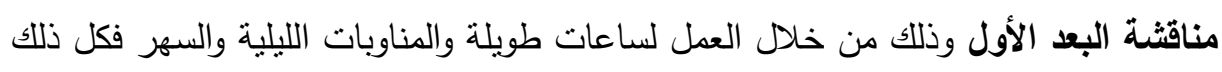

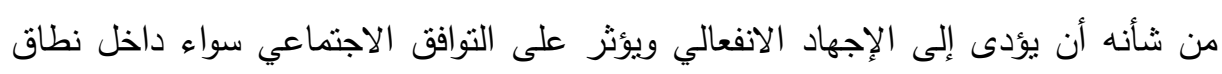
العمل أو خارجه أو مع أفراد الأسرة.

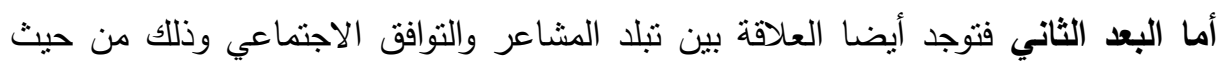

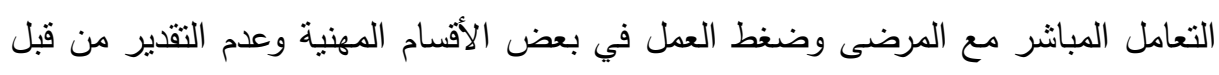

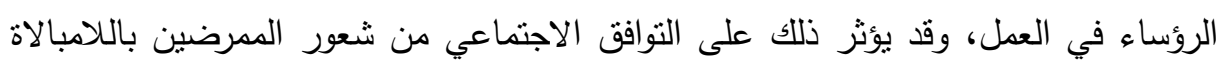

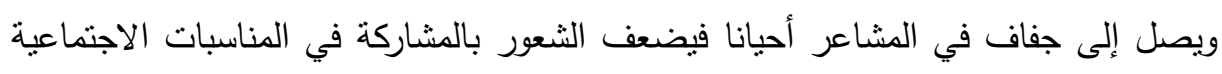

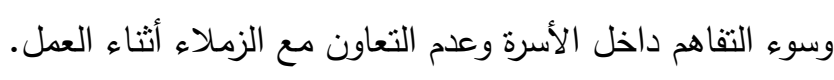

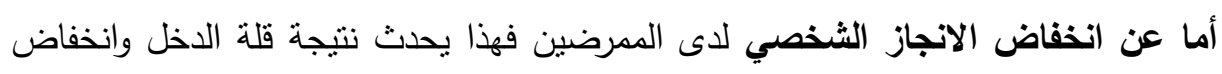

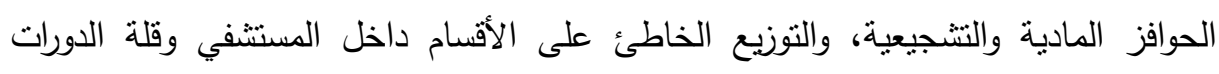

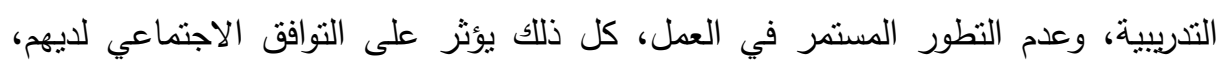

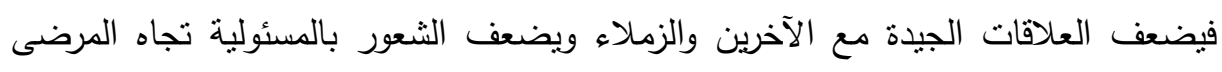

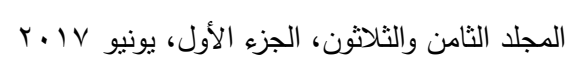


والمجتمع، وهكذا يؤثز الاحتراق المهني بأبعاده الثلاثة على التوافق الاجتماعي لدى الممرضين داخل محيط العمل وخارجه سواء على مستوى الأسرة أو حضور المناسبات الاجتماعية.

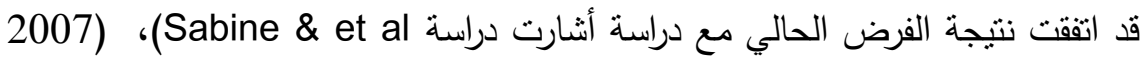
إلى أن الضغوط التنظيمية والاجتماعية، غموض الدور في العمل ترتبط بمسنويات عالية من درانه

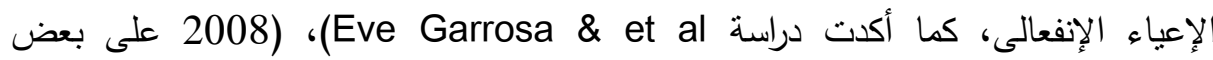
المتغيرات المنبئة بصورة دالة على الاحتراق النفسي من أهمها الصراع داخل بيئة العمل، في حين اختلفت نفس الدراسة مع الدراسة الراهنة في الهدف من حيث سعيها إلى معرفة مدى الهى

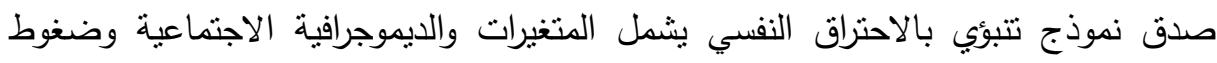

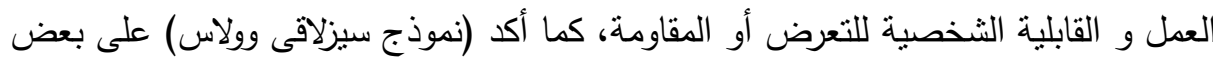
العناصر الخاصة ضغوط العمل وتفاعلها معا في خلق الضغوط التي تقع على الفرد والتي تترك أثزها على مستوى الفرد، من حيث أثزها السلبي على مستوى المنظمة التي يعمل بها

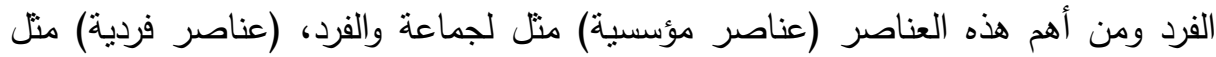

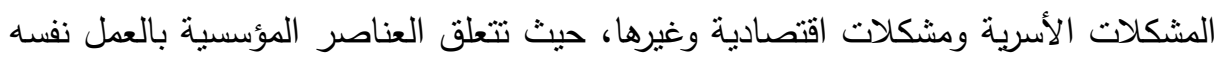

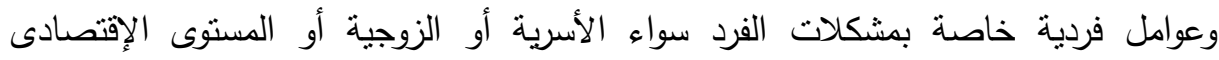
والإجتماعى، إلى جانب تأثنر البيئة المادية من حوله، واختلاف الفروق الفردية بين الأفراد واختلاف استجاباتهم نحو الضغوط، وقد أكدت بعض النظريات النفسية الأخرى منل (نظرية التحليل النفسي) من حيث تأكيد فرويد على أهية الخبرات اللاشعورية في تشكيل شخصية

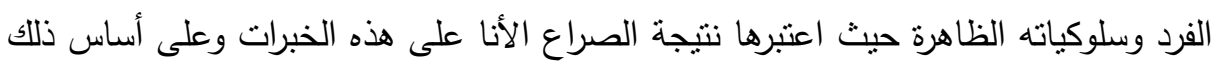

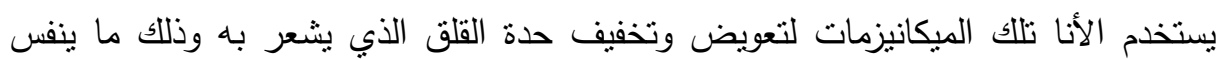
الأعراض التي يشعر بها الفرد نتيجة للضغوط الثنديدة في العمل حيث عدم قدرته في مواجهة هذه الضغوط تجعله يقوم بكبت هذه الرغبات التي يشعر بها حتى يستمر في عمله لأي سبب. الفرض الخامس توجد علاقة ارتباطية ذات دلالة إحصائية بين بيئة العمل ودرجات الاحتراق المهني لاى كلاً من الأطباء والممرضين. 
جدول(ه): العلاقة الارتباطية بين بيئة العمل ودرجات الاحتراق المهني لدى كلاً من الأطباء والممرضين

\begin{tabular}{|c|c|c|c|c|}
\hline \multicolumn{4}{|c|}{ بينـا العصل } & \multirow{3}{*}{ ابعاد الاحتراق المهني } \\
\hline \multicolumn{2}{|c|}{ الممرضون } & \multicolumn{2}{|c|}{ الإطباء } & \\
\hline المنالاية & معامل انتباط & المبنوية & معامل انتباط & \\
\hline 0.000 & $-0.551^{\text {sex }^{2}}$ & 0.000 & -0.7 & 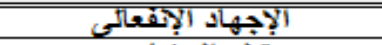 \\
\hline 0.000 & $-0.531^{(8 *)}$ & 0.000 & $-0.664^{(88)}$ & تبلي المشّاعر \\
\hline 0.000 & $-0.612^{(8 *)}$ & 0.000 & $-0.756^{(8 *)}$ & انخفاض الإججاز الثخصي \\
\hline 0.000 & $-0.671^{(8 *)}$ & 0.000 & $-0.756^{(8 *)}$ & إجمالي مقياس الاحتراق \\
\hline
\end{tabular}

يتضح من الجدول السابق للعلاقة الارتباطية بين بيئة العمل ودرجات الاحتراق المهني لدى كلاً من الأطباء والممرضين يتضح التالي: • توجد علاقة عكسية ذات دلالة إحصائية عند مستوى معنوية (0.05)بين بيئة العمل بلاهل

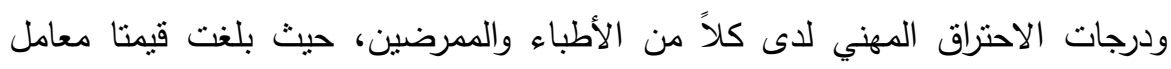
الإرتباط 0.720-)، (0.551-الكل من عينة الأطباء وعينة الممرضين على التوالي.

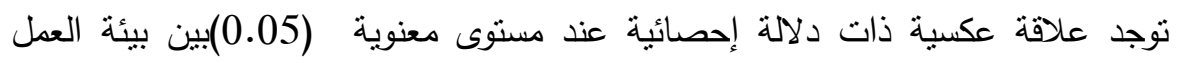
ودرجات الاحتراق المهني لدى كلاً من الأطباء والمررضين، حيث بلغت قيمتا معامل

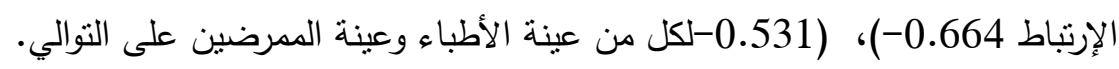

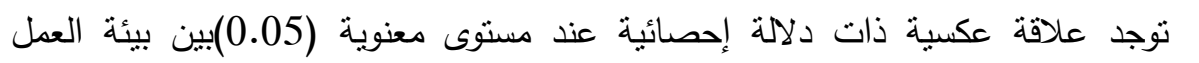

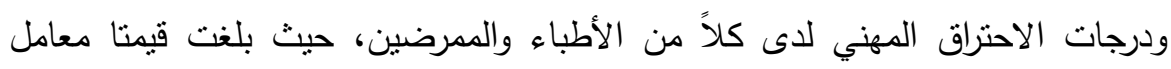
الإرتباط 0.756-)، (012-لكل من عينة الأطباء وعينة الممرضين على التوالي. • توجد علاقة عكسية ذات دلالة إحصائية عند مستوى معنوية (0.05) بين إجمالي بيئة

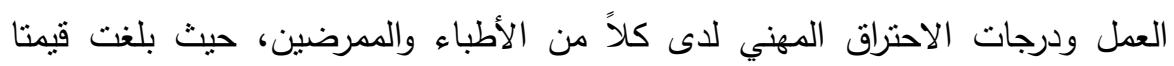

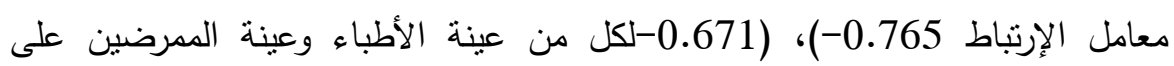
التوالي.

لذا يثبت صحة الفرض الخامس :توجد علاقة ارتباطية ذات دلالة إحصائية بين بيئة العمل ودرجات الاحتراق المني لاى كلاً من الأطباء والممرضين. 
ويتضح ذلك البعد الأول من خلال تدهور بيئة العمل من عدم وضوح المهام بالنسبة لمعظم

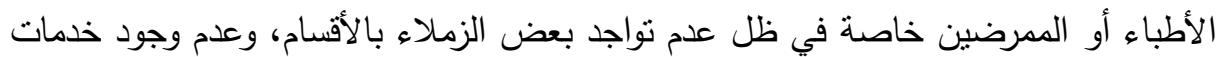

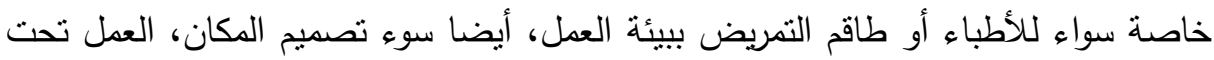
درجة حرارة عير مناسبة ونقص التهوية داخل حجرات المستشفي فكل هذا يؤثر على الإجهاد

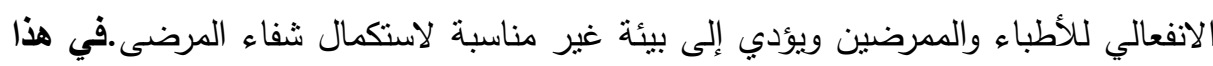

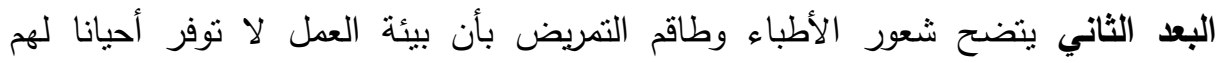

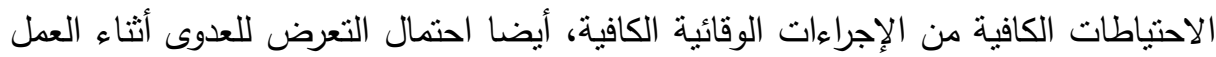

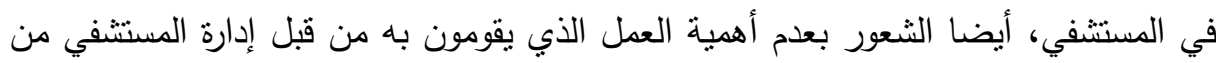

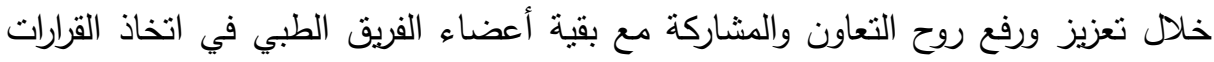
وافتقار المساعدة داخل العمل فكل هذا يؤدى بهم إلى شعورهم بجفاف في مشاعرهم وعدم

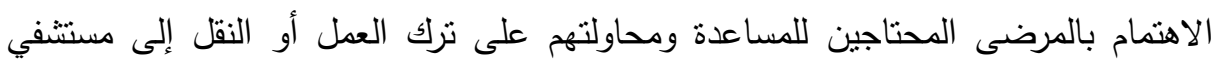

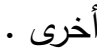

أما البعد الثالث من حيث تأثير بيئة العمل على مستوى الانجاز الثخصي فنجد أن لبيئة

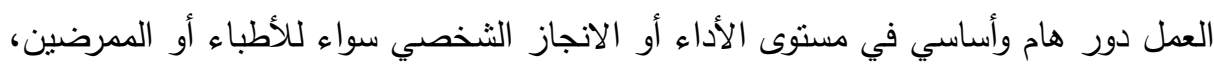
من حيث عدم نوافر العدد الكافي والمناسب من أفراد الطاقم الطبي، ونقص التكنولوجيا اللازمة التهة والمناسبة لتبادل الأوامر والاتصال داخل المستشفي، أيضا سوء توزيع الهيكل التتظيمي الخاص بالأطباء والممرضين في المستشفي، نقص التجهيزات اللازمة لأداء العمل فكل ذلك يؤثر بشكل سلبي مباشر على الانجاز الثخصي ويؤدى إلى انخفاضها، كما أيضا عدم التطور

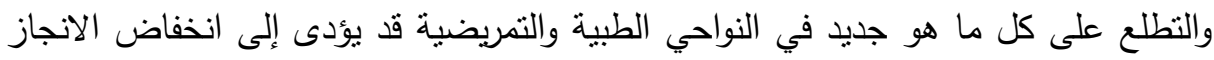

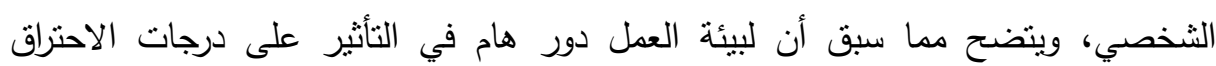
المهني بأبعاده الثلاثة لدى الأطباء والممرضين، من حيث نقص الإنكانيات والتجهيزات اللازمة لأداء العمل ونقص الأدوات الطبية وسوء تصميم المكان ونقص التهوية وقلة العدد المناسب من العاملين وأفراد الطاقم الطبي وعدم وضوح الدور والمهام وغياب الهيكل التتظيمي 
وغير ذلك مما سبق يؤدى إلى الوصول لدرجة عالية من الاحتراق المهني لاى كلا من الأطباء والممرضين.

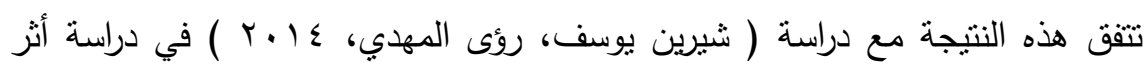

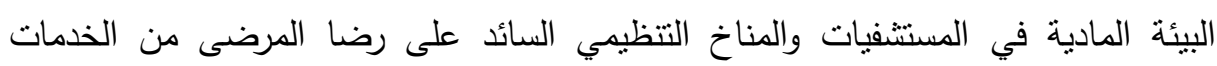
المقدمة لهم دون العاملين بالمستثنفيات من الأطباء والممرضين.

\section{التحوسياهي}

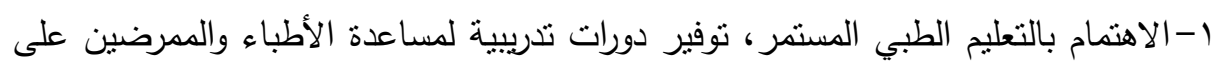

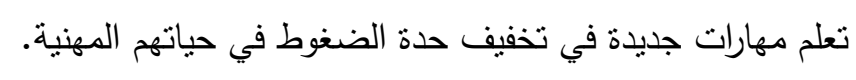

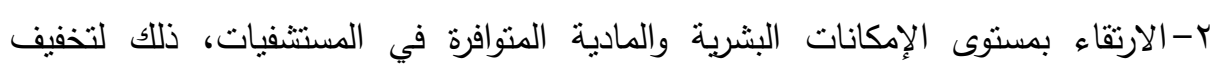

$$
\text { الاحتراق المهني الناتج عن تدهور بيئة العطل. }
$$

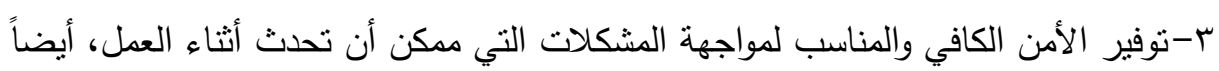

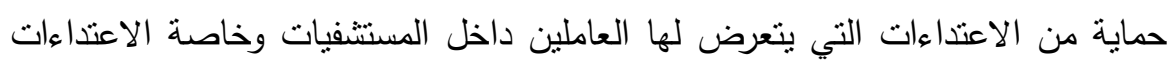

$$
\text { التي تقع على الأطباء في أقسام الطوارئ والاستقبال. }
$$

ع-تتسيق ساعات العمل بين أفراد الفريق الطبي أنثاء المناوبة حتى لا لا يحدث ارتباك أثناء

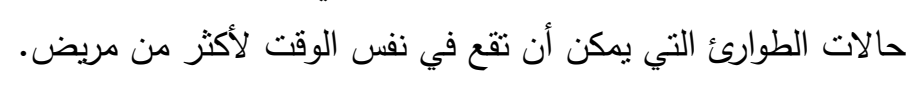

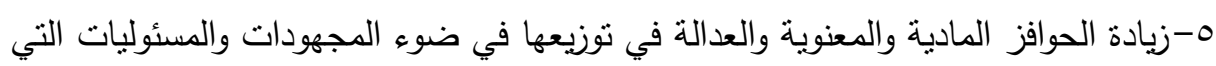

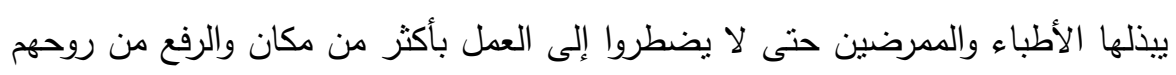

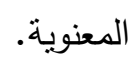

\section{المراليع}

أميرة فايق أمين(7 ( • ب):الرضا الوظيفي كمتغير وسيط في العلاقة بين الاحتراق النفسي

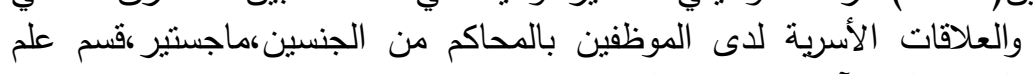

النفس،كلية الآداب، جامعة القاهرة. 


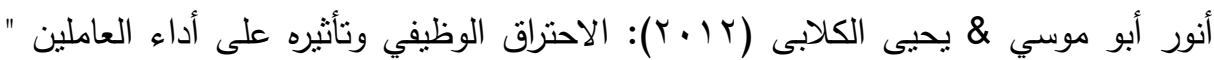

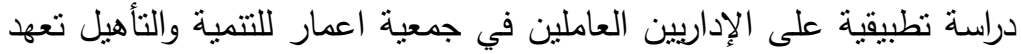

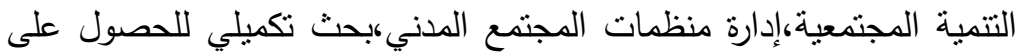

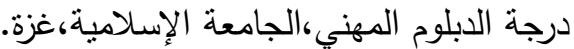

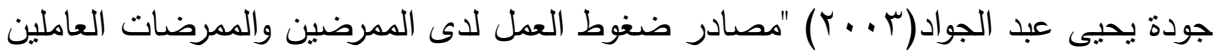
في مسنتفيات شمال الضفة الغربية، ماجستير غير منشورة، جامعة الغينة النجاح الوطنية،نابلس، فلسطين.

حامد زهران(0 . ץ): الصحة النفسية والعلاج النفسي، عالم الكتب، الطبعة الرابعة، القاهرة.

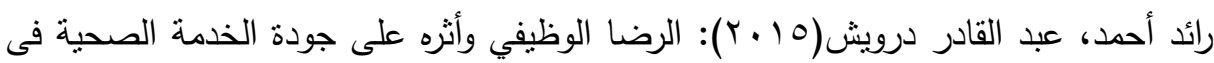

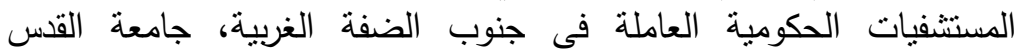

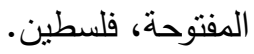

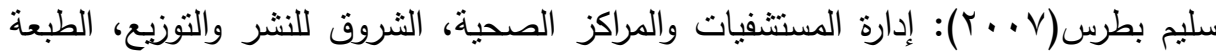
الثانية

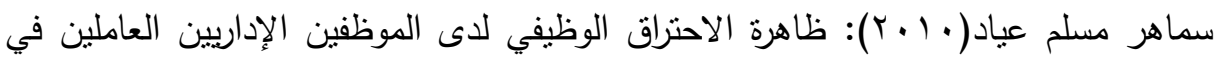

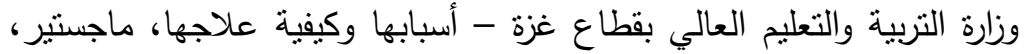

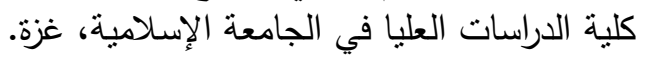

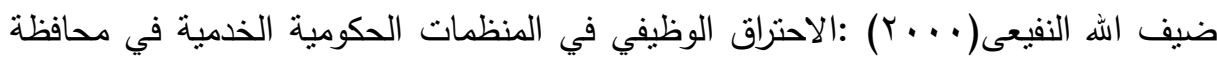

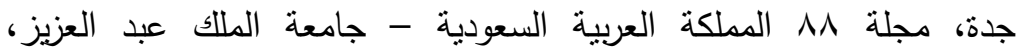

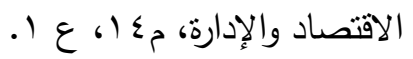

عبد الرحمن أحمد محمد هيجان(991 (191): ضغوط العمل، معهذ الإدارة العامة، الرياض. غازي فرحان(999 (1): خدمات لإيواء في المستتفيات، دار زهران للنشر والتوزيع، عمان. محب عبداللطيف عبدالباقي(10 • ب):الاحتراق النفسي وعلاقته بكل من القلق والاكتئاب لدى

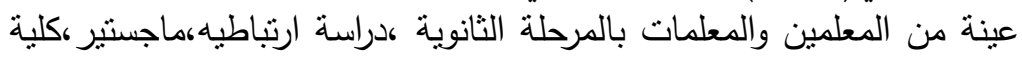
الآداب،جامعة عين شمس.

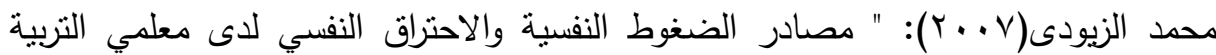

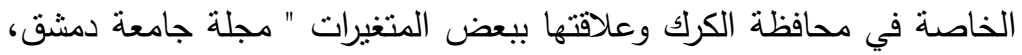

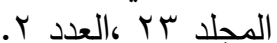




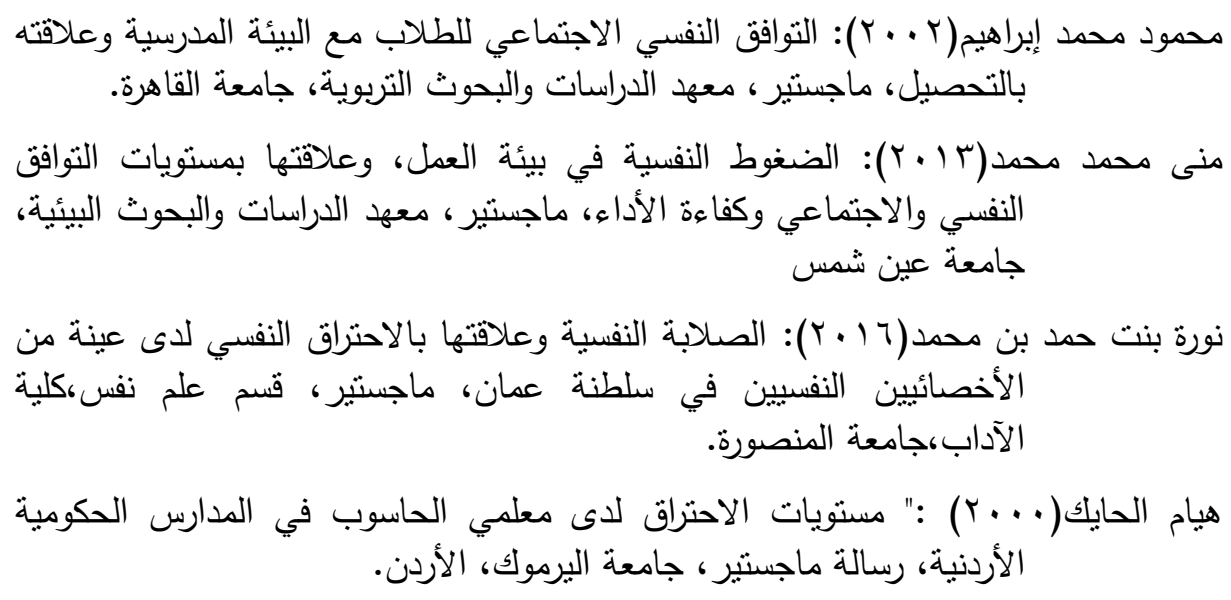

Elisabeth Grebot ،(2008) Stress et burnout-sut au travail ed. D' organization ‘Paris.

Halbsleben ‘Jonathon \& Ronald Buckle, (2004) :" Burnout in organizational life, furnal of management 30 (6)

Kirsi Ahola \& et al: occupational burn out and medical certified sickness absence: A population - based stuff of finish employees journal of psychosomatic research ،volume 64, Issue 2, February ،2008, pp185.

Lindo et al (2006) :Meatal weak- being of doctors and Nurses in two hospital in king ton ،Jamaica west Indian Medical Journal ، 55 (3): $153-159$

Mojoylinola ,(2008): Effects of job stress on health rpersonal and work behaviour of nurses in public hospitals in Ibadan Meteropolis ،Nigeri ،Department of social work faculty of education suniversity of Ibadan Nigeria.

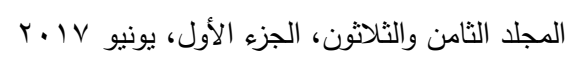




\title{
OCCUPATIONAL BURN-OUT AND ITS RELATION \\ TO PSYCHOLOGICAL AND SOCIAL ADJUSTMENT \\ FOR PHYSICIANS AND NURSES WORKING IN GOVERNMENTAL AND PRIVATE HOSPITALS
}

\author{
Ahmed, G. S. ${ }^{(1)}$; El-Sayed, A. E. ${ }^{(2)}$; Kamal El-Din, Mona, M. ${ }^{(3)}$ \\ and Ahmed, M. M. ${ }^{(4)}$ \\ 1) Institute of Post Graduate Childhood Studies, Ain Shams University \\ 2) Faculty of Medicine, Ain Shams University.3) Faculty of Women, \\ Ain Shams University
}

\begin{abstract}
This research aims to reveal the relationship between combustion and professional both government and private hospitals with a group of doctors, nurses and verify the existence of differences between the combustion professional levels they have in government and private hospitals, as well as stand on the most important features that characterize both the government and private hospitals environment, where they formed (sample doctors) from (162) doctors in some government hospitals, the number (127) of physicians in some private hospitals, (sample nurses) consisted of (214) in some government hospitals, the number (103) some Almstchwiat own, the researcher used the descriptive and comparative depending on combustion vocational scale for doctors and other nurses, as well as the use of ergonomics measure as a means of serving the goal of research, I have found research to some of the results of the most important of the existence of correlation function relationship between combustion and professional compatibility and psychosocial among both physicians and nurses, as well as the physical environment conditions in hospitals play a role a significant increase in the level of the combustion professional respondents, the study also recommended a set of recommendations, the

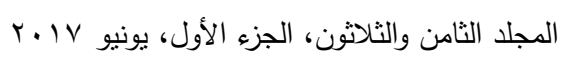


most important of the importance of the need to develop a strategy that includes improving the quality of medical services through the public availability of the right to work and raise the income of employees and the level of other material resources plan 